\title{
(5)
}

ברונים הבאים למעבר ארז

Welcome to Erez crossing

اهمالا وسهالاً بكم في معبر ايرز 


\section{So Near and Yet So Far}

Implications of Israeli-Imposed Seclusion of Gaza Strip on Palestinians' Right to Family Life

January 2014 
Researched and written by Naama Baumgarten-Sharon

Edited by Yael Stein

Translated by Michelle Bubis

Language editing by Shuli Schneiderman

Data coordination Dunia Abbas, Suhair 'Abdi, Noa Atlas, Silan Dallal, Yonatan Kanonich, Omri Metzer, Andrea Szlecsan

Field research 'Atef Abu a-Rub, Salma a-Deb'i, Khaled al-'Azayzeh, lyad Hadad, Kareem Jubran, Muhammad Sabah, Suha Zeid

Legal counsel Adv. Anat Gonen, Adv. Bilal Sbihat, Adv. Tal Steiner

Cover photo Woman waiting at Erez Crossing, Gaza-Israel border. Photo by Oren Rosenfeld, 19 March 2013.

ISBN: 978-965-7613-09-2

B'TSELEM - The Israeli Information Center for Human Rights in the Occupied Territories was founded in 1989 by a group of concerned Israelis. It endeavors to document and educate the Israeli public and policymakers about human rights violations in the Occupied Territories, combat the phenomenon of denial prevalent among the Israeli Public, and help create a human rights culture in Israel.
HaMoked - Center for the Defence of the Individual, founded by Dr. Lotte Salzberger, is a human rights organization established in 1988 against the backdrop of the first intifada. HaMoked's mandate is to safeguard the rights of Palestinians living under Israeli occupation. HaMoked acts to enforce standards and values rooted in International Humanitarian Law and International Human Rights Law. 


\section{Table of Contents}

1. Introduction ........................................................ 5

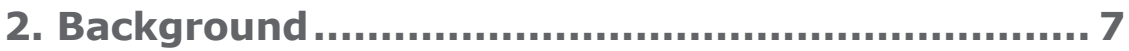

3. Travel between Gaza and the West Bank .......... 11

A. Relocating from Gaza to the West Bank................... 12

B. Visits by Gaza residents to the West Bank ................. 22

C. Passage from the West Bank to the Gaza Strip ............ 25

4. Travel between the Gaza Strip and Israel .......... 35

A. "Split family procedure" - Israeli citizens or residents married to Gaza residents..................... 36

B. Visits by Israelis to the Gaza Strip $\ldots \ldots \ldots \ldots \ldots \ldots \ldots \ldots \ldots . \ldots 4$

5. Harm to women caused by Israel's policy.......... 49

6. Israel's policy considered in view of international law .......................................... 57

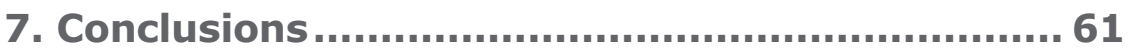

8. Appendix - Response by the Ministry of Justice 


\section{Introduction}

"Gaza and the West Bank seem like two separate and distant planets, with no way of getting from one to the other," says Maha Hijawi, who was born in the Gaza Strip and now lives with her husband and children in the West Bank. This is how she feels about being cut off from her family of birth and having her children separated from their extended family in the Gaza Strip. ${ }^{1}$

After Israel occupied the West Bank and the Gaza Strip in 1967, it allowed Palestinians relatively free passage between the West Bank, the Gaza Strip and Israel. This policy facilitated both the renewal of family ties and the forging of new ones through marriage and work. Gaza and West Bank residents who married Israeli citizens or residents of East Jerusalem with Israeli ID cards could receive permanent residential status in Israel through the process of "family unification".

In 1988 Israel began restricting entry by Palestinians into the country, even by Palestinians who wished to enter Israel for the purpose of travel between Gaza and the West Bank. Over the years, restrictions grew more stringent. Current procedure almost entirely prohibits Palestinians from entering Israel, no matter the grounds.

These restrictions on Palestinian movement altered reality for couples in which the partners did not come from the same area. Prior to these restrictions, such couples could choose their place of residence: Gaza residents who married West Bank residents could move in with their spouses and change their address to the West Bank; Gaza residents who married Israelis could obtain legal status in Israel, upon granting of an application for family unification. Since Israel began imposing restrictions on travel into and out of Gaza, these couples no longer have a choice. Instead, their lives are governed by a host of bureaucratic constraints that deny them a normal routine: they cannot move freely between Gaza and the West Bank, and the amendment to Israel's Nationality Law does not enable family unification in Israel, forcing Israelis married to Gazan residents to relocate to Gaza or to live apart from their spouses.

1 Testimony taken by Salma a-Deb'i on 24 April 2013. 
This report reviews the various procedures imposed on Palestinian families some of whose members live in Gaza, i.e., families that are split between Gaza and the West Bank or between Gaza and Israel (including East Jerusalem). Israel annexed East Jerusalem and imposed Israeli law and administration there in contravention of international law. Consequently, despite being a part of the West Bank, East Jerusalem residents are subject to a different legal system than other West Bank residents. In this report, B'Tselem and HaMoked: Center for the Defence of the Individual (hereinafter: HaMoked) will address the legislation in practice. Implementation of the procedures imposed on such divided families will be explored in view of cases brought to HaMoked. In cases brought before it, HaMoked handled contact with the military authorities in charge of issuing movement permits - the Civil Administration in the West Bank and the Coordinator of Government Activities in the Territories (hereinafter: COGAT) and the District Coordination Office (hereinafter: DCO) in matters concerning the Gaza Strip - and filed petitions to Israel's High Court of Justice (hereinafter: HCJ). While these cases illustrate the main problems that such families encounter in dealing with authorities, they reflect only those instances in which families turned to HaMoked for assistance. Many Palestinians who do not approach human rights organizations for help in dealing with the authorities are unable to manage the military system alone. Consequently they may refrain from applying at all, or do not persist upon denial of their initial application. One chapter in this report examines the unique implications that Israel's policy has on women who, in accordance with common practice in Palestinian society, are usually the ones expected to leave their family of origin after marriage. 


\section{Background}

After occupying the Gaza Strip and the West Bank in 1967, the Israeli military declared these areas a closed military zone. ${ }^{2}$ In 1972, universal exit permits were issued, granting Palestinians practically free movement between Gaza and the West Bank and between the two occupied territories and Israel, including East Jerusalem, where Israeli law had been applied in contravention of international law. ${ }^{3}$ Israel allowed Palestinians to relocate from Gaza to the West Bank and vice versa quite easily. The new address was updated in the Palestinian population registry, which was administered by the Israeli military until 1981, and then by the Civil Administration, which was established by the military to handle the civil matters of the local Palestinian population.

Gaza and West Bank residents who married Israeli citizens or residents could submit a request for family unification and, after a process of several years, obtain legal status in Israel. This reality facilitated the renewal of family ties, social contacts and trade relations between families that had been severed since 1948.

In 1988, during the first intifada, the military revoked the universal exit permit. ${ }^{4}$ In 1991 the military decreed that residents must obtain individual permits. ${ }^{5}$ The consequences of this change were not immediately apparent, because during the first few years after the revocation of the universal permit, the Civil Administration issued many individual permits for relatively long periods of time. This meant that most Palestinians were able to carry on entering Israel routinely, including as a gateway between Gaza and the West Bank.

2 Order Closing Area (Gaza Strip and Northern Sinai) (No. 1), 5727 - 1967; Order Regarding Closing of Territory (West Bank Area) (No. 34), 5727 - 1967.

3 General Exit Permit (No. 5) (Judea and Samaria), 5732 - 1972. A similar permit was issued for the Gaza Strip.

4 Order Regarding Suspension of the General Exit Permit (No. 5) (Temporary Order) (Judea and Samaria), 5748 - 1988. A similar order was issued for the Gaza Strip.

5 Order Regarding Suspension of the General Exit Permit (No. 5) (Temporary Order) (Judea and Samaria), 5751- 1991. A similar order was issued for the Gaza Strip. 
Over time, Israel adopted a stricter policy, gradually reducing the number of individual permits granted. In March 1993, after 16 Israelis had been killed by Palestinians in Israel and in the Occupied Territories, Israel imposed a general closure on Gaza and the West Bank, which has remained in effect ever since. Along with the closure, the criteria for permits to exit the Occupied Territories were made considerably stricter, and the number of permits issued by the Civil Administration dropped drastically. The extent of the closure varies. At times, it is raised to the level of "full closure"- usually after high-casualty terror attacks, due to intelligence alerts, or during Jewish and Israeli holidays. This level renders all permits void. The closure had an immediate impact on all residents of the Occupied Territories, as every attempt to obtain a permit from the Civil Administration entailed a bureaucratic hassle. All lifecycle changes and daily needs had to be compressed into categories and made to fit into blanks in forms. This naturally falls far short of encompassing the complex realities of individual lives.

When the first Oslo Accord (Cairo Agreement: Gaza and Jericho) was signed in May 1994, Palestinian independent rule was established in the Gaza Strip, and Israeli citizens or residents could enter it subject to individual permits. This resulted in the establishment of the "split family procedure" that determines how Israelis married to Gazans may visit or establish residence in the Gaza Strip. The procedure remained in force during the second intifada, with the exception of several periods when it was suspended.

On 22 September 2005, Israel completed its Disengagement Plan in which it evacuated all Israeli settlements in the Gaza Strip and withdrew its military forces from the area. ${ }^{6}$ Since then, as a rule, Israelis are not allowed to enter the Gaza Strip. The declared rationale behind this is preventing Israelis from returning to the evacuated settlements. ${ }^{7}$ The prohibition also applies to Israeli citizens and residents who have relatives in Gaza. A new procedure, much like the one in place before the Disengagement, was put into effect to handle cases of Israelis married to Gaza residents.

In June 2007, after Hamas seized control of the Gaza Strip, Israel imposed a siege on Gaza. It closed the border crossings between Israel and Gaza, thereby denying residents of Gaza almost any possibility of exit or entry, as well as blocking most

6 "Declaration Stating the End of Military Rule", signed by OC Southern Command Maj. Gen. Dan Harel, 22 September 2005. See http://www.hamoked.org.il/items/7931.pdf (in Hebrew).

7 See Disengagement Plan Implementation Law 5765-2005, Articles 22-25. 
imports and exports. Although Israel has eased some aspects of the siege over the years, mostly after the 2010 flotilla incident, the restriction on entering Gaza or travel from Gaza into Israel remains in effect.

In June 2010, Egypt opened Rafah Crossing on a partial basis, opening it for full operation in December 2011. When the crossing was open, Gazans could leave the Gaza Strip and West Bank residents could enter it. However, the recent political upheavals in Egypt have had an impact on the regular opening of the crossing. As of July 2013, Egypt has restricted passage through the crossing to limited numbers of people. Even when the crossing is open, it serves as an inadequate solution for visits by split families: Israel does not allow Gaza residents to enter the West Bank through Allenby Bridge; for West Bank residents, taking that route to Gaza is lengthy, arduous, and usually beyond their means.

Israel's official position at present is that Gazan spouses of West Bank residents or of Israeli citizens or residents have no right to enter Israeli territory, even if only for the purpose of transit to reach the West Bank. The Israeli position is as follows:

Residents of the Gaza Strip, like all other foreign nationals, have no legal right to enter Israel for any need whatsoever. The point of departure, which the Court has reiterated, is that the state has the broad authority and discretion to determine who enters its territory, and that foreign nationals have no legal right to enter Israel's sovereign territory... This principle is derived both from international law, especially as it relates to the principle of sovereignty, and to the Law of Entry into Israel, which accords the executive branch extremely broad discretion regarding the entry of foreign nationals into its territory. ${ }^{8}$

Apart from the reasoning concerning statehood and sovereignty, Israel cites security concerns as justification for collectively prohibiting Gaza residents from entering its territory. The explicit rationale is that any movement between Gaza and the West Bank may pose a security risk, even when the person requesting permission is not considered a threat in him/herself. According to that argument, "allowing residents of Gaza to move freely 
among these areas places the State of Israel and its residents in clear danger - even more so when the case is allowing residents of Gaza to travel through the territory of Israel".9

On that basis, the state's current position is that entry by Gaza residents into Israel, including for the purpose of reaching the West Bank, "is limited to exceptional humanitarian cases only, particularly urgent medical cases, subject to the Respondents' discretion, who are under no obligation in this matter". 10 


\section{Travel between Gaza and the West Bank}

Under the Oslo Accords, "[t]he two sides view the West Bank and the Gaza Strip as a single territorial unit, whose integrity will be preserved during the interim period." ${ }^{11}$ In order to implement this in practice, the accords dictated arrangements for operating a "safe passage" along two routes connecting the northern and southern West Bank with the Gaza Strip. ${ }^{12}$ The passage was opened only several years later, through the southern route only, and operated for less than a year from October 1999 to September 2000, when the second intifada began.

Although this position was never officially rescinded - and the HCJ even confirmed that the two areas comprise a single territorial unit ${ }^{13}$ - Israel's declared policy has changed and now considers the West Bank and the Gaza Strip "two separate and different areas". ${ }^{14}$ In response to an HCJ petition by a resident of Gaza who wished to relocate to the West Bank for professional training, the state explained its new position as follows: "The Appellant has no given right, under Israeli law or under international law, to move from the Gaza Strip, an area that is no longer under Israeli control, to the West Bank, which has been declared a closed military zone by the military commander". ${ }^{15}$ Accordingly, the state announced that it had the authority to "deny requests for passage or relocation of Palestinians from Gaza to the West Bank, except in unusual humanitarian cases."16

11 Declaration of Principles on Interim Self-Government Arrangements, Washington, D.C., 13 September 1993, Article 4. Similar phrasing appeared in the Oslo I Accord and the Oslo II Accord.

12 Agreement on the Gaza Strip and Jericho Area (Oslo I), Cairo, 4 May 1994, Annex I, Article IX; IsraeliPalestinian Interim Agreement on the West Bank and Gaza Strip (Oslo II), Washington, D.C., 28 September 1995, Annex I, Article X.

13 HCJ 7015/02, 'Ajuri et al. v. Commander of the Military Forces in the West Bank et al., decision, 3 September 2002.

14 Letter from Civil Administration to HaMoked, 15 April 2008.

15 HCJ 2748/12, Muslem et al. v. Commander of the Military Forces in the West Bank et al., preliminary response on behalf of the Respondents, 10 April 2012, Article 4. See, also, HCJ 1992/13, Tlatini et al. v. Commander of the Military Forces in the West Bank et al., preliminary response on behalf of the Respondents, 10 April 2013, concerning passage from the West Bank to the Gaza Strip to visit a sick daughter.

16 HCJ 660/08, 'Amer et al. v. Commander of the Military Forces in the West Bank et al., notice on behalf of the Respondents, 1 December 2008, Article 28. 
Under current procedure, it is possible to travel between the West Bank and the Gaza Strip in one direction only. The military permits passage only from the West Bank to Gaza - and even then, only after the person pledges to "relocating" to Gaza permanently - whereas requests to move from Gaza to the West Bank are usually denied outright. Visits are allowed only for humanitarian needs, usually under tragic circumstances.

In recent years, Israel has treated Palestinians whose registered addresses are in Gaza but who actually live in the West Bank as "illegal aliens", unless they have a special permit. This policy was instated piecemeal; in some cases, the procedures were formulated only after the policy was already implemented in practice.

\section{A. Relocating from Gaza to the West Bank}

From 1967 until the early 1990s, Palestinians could move between the West Bank and the Gaza Strip and update their address accordingly in the population registry without having to obtain any official permits. The Interim Accords, signed in 1995, specified that "[p]owers and responsibilities in the sphere of population registry and documentation in the West Bank and the Gaza Strip will be transferred from the military government and its Civil Administration to the Palestinian side."17 The latter was charged with informing Israel "of every change in its population registry, including, inter alia, any change in the place of residence of any resident." ${ }^{\prime 18}$

This arrangement enabled Israel to retain control of the Palestinian population registry. In 2000, after the second intifada broke out, Israel suspended all updates to its copy of the registry regarding changes of address from Gaza to the West Bank. Since then, Gaza residents who have moved to the West Bank have been unable to update their home address in the registry. Yet even prior to the suspension of updates, Israel did not always automatically approve changing a Gaza address to a West Bank one.

According to Israeli estimates, there are some 19,000 adults and 2,500 minors currently living in the West Bank, whose home address is listed as the Gaza Strip in the Israeli copy of the Palestinian population registry. ${ }^{19}$ However, the state

17 Israeli-Palestinian Interim Agreement on the West Bank and the Gaza Strip (Oslo II), Washington, D.C., 28 September 1995, Annex III (Protocol Concerning Civil Affairs), Article 28 (1).

18 Ibid., Article 28 (10).

19 HCJ 2088/10, HaMoked v. Commander of the Military Forces in the West Bank et al., notice on behalf of the Respondents, 31 January 2012, parags. 7-9. 
has made it clear in the past that its figures do not necessarily reflect reality, as precise computer documentation was not kept of people moving between the two areas and problems of compatibility between the different computer systems. ${ }^{20}$

\section{Change of residence: Moving from the Gaza Strip to the West Bank}

Towards the end of 2007, HaMoked handled several cases that revealed that the military had begun to issue permits to Gaza residents that allow them to be in the West Bank. HaMoked began inquiring into the matter and, in March 2008, received a letter from COGAT stating that an internal decision had been reached, without legislation or publication, that "as of November 2007, any resident of Gaza who is in the West Bank must hold a 'permit to stay in Judea and Samaria', and the permit is intended for that purpose only". The letter also detailed the procedures that are to govern these arrangements. ${ }^{21}$

In March 2009, the military sent HaMoked a new procedure, formulated subsequent to $\mathrm{HCJ}$ petitions that the latter had submitted concerning women from the Gaza Strip who had married men from the West Bank. ${ }^{22}$ The new procedure almost entirely bars Gaza residents from official relocation to the West Bank, even if they have lived there for years, and allows for submission of requests only in exceptional cases. ${ }^{23}$

According to procedure, the applicant must meet two prerequisites: security clearance (both of the applicant and of the West Bank resident with whom he or she wishes to live); and first-degree kinship with that person. The authorities will review the request only if these criteria are met and only if the applicant fits one of the following three categories (note: marriage is not one of the categories): chronically ill patients, minors under the age of sixteen who have lost a Gazan parent, and elderly people in need of nursing care who have no relative of any degree in Gaza to care for them. ${ }^{24}$

20 See, for example, letter from COGAT to HaMoked, 2 June 2010, parags. 4-8:

http://www.hamoked.org.il/files/2010/112281.PDF (in Hebrew).

21 Letter from COGAT Spokesperson Major Peter Lerner to HaMoked, 18 May 2008.

22 HCJ 2680/07, 'Amer et al. v. Commander of the Military Forces in the West Bank; HCJ 2905/08,

Abu Snar et al. v. Commander of the Military Forces in the West Bank; HCJ 3952/08, Hamidat et al. v. Commander of the Military Forces in the West Bank; HCJ 3911/08, Bardawil et al. v. Commander of the Military Forces in the West Bank.

23 Letter from COGAT to HaMoked, 8 March 2009.

24 Ibid. 
The procedures also state that, in cases where the request was granted, the applicants will be given temporary permits for six months only. The permits can be renewed for an additional six months, and then once a year, up to seven years from the original date of issuance. Only then will the possibility of granting "permanent residence" in the West Bank be considered, with no assurance that it will be approved. The temporary permit can be revoked under three conditions: lack of security clearance, termination of the humanitarian need, and leaving the West Bank for Gaza or another destination for a long period of time. ${ }^{25}$

HaMoked filed a petition of principle with the HCJ against this procedure, arguing that its criteria deny Gaza residents any possibility of living with their partners in the West Bank, thereby violating their right to family life. The three conditions under which a permit may be granted are so extreme that it is almost impossible to imagine a single case of a person meeting them. In theory, it will always be possible to claim that some relative, no matter how distant, exists and can care for the orphaned child or for the debilitated elderly person, even if they have absolutely no contact. The authorities can then declare that the applicant does not meet the criteria and decline the request. Among other things, the petition stated that "with a single stroke of the pen, the new procedure severs the fabric of life that exists between Gaza and the West Bank, de facto erasing Palestinians' right to family life while splitting families apart, separating partners, parents from children, and grandparents from grandchildren. In effect, it is the final nail in the coffin marking the connection between Gaza and the West Bank and their conceptualization as a single territorial unit (and in future, maybe, their being one Palestinian state)".26

The HCJ rejected the petition on the grounds that the Court's interference with the state's discretion could not be justified, after having accepted the state's position that its decisions are based on security concerns, and that "the formulation of a restricted policy in this area is commensurate with the Respondents' duty to protect the safety of Israel and the region".27 However, regarding the stated exceptions to the rule, former Chief Justice Dorit Beinisch 
emphasized that "it seems that they have been severely restricted, too much so under certain circumstances... It may be appropriate to apply the exceptions in such a way that will enable these groups to remain in contact with their first-degree relatives - even if there are more distant relatives within the Gaza Strip".28

In accordance with the HCJ's comments, COGAT made several amendments to the procedure, publishing a new version in July 2013. Contrary to the Court's instructions, the amendments were minor, keeping travel between Gaza and the West Bank limited to exceptional circumstances:

1. In the case of patients requiring nursing care - passage from Gaza to the West Bank will be permitted only to applicants without a first-degree or seconddegree relative (nuclear family or grandmother, grandfather, grandchild) who can care for them in Gaza.

2. In the case of an orphaned minor who has lost a Gazan parent - the condition of a relative in Gaza who can care for him or her, however distant, has been cancelled.

3. In the case of the elderly - the condition is having no first-degree relative in Gaza to care for them.

4. In exceptional cases, at COGAT's discretion, permits may be given to first- or second-degree relatives of a West Bank resident, if the request pertains to exceptional humanitarian circumstances that render the applicants unable to continue living in Gaza. The procedure explicitly states that marriage and joint children are not considered humanitarian circumstances in this context. ${ }^{29}$

\section{Retroactive change of address}

In November 2009, in proceedings concerning a petition by HaMoked, Israel declared that any persons in the West Bank whose registered address is in the Gaza Strip are considered "illegal aliens", and it is within the military commander's authority to expel them from the West Bank and send them back to Gaza. However, the state did commit not to expel Palestinians who had

28 Ibid., parag. 19 of ruling.

29 "Procedure for Processing Requests of Gaza Residents to Settle in the West Bank", July 2013, Articles

10-11. For the full procedure, see COGAT website: http://www.cogat.idf.il/2027-he/Cogat.aspx (in Hebrew). 
moved to the West Bank from Gaza before October 2000, unless there was a security file on them. The state added that, should a person be expelled from the West Bank and sent back to Gaza despite this policy, or should that person reach Gaza for whatever reason and be "stuck" there, he or she would be allowed to return home to the West Bank. ${ }^{30}$ In April 2013, as part of the proceedings in a petition of principle that HaMoked filed, the state expanded this commitment to include any person who had moved from Gaza to the West Bank before the Disengagement Plan was completed in September 2005..$^{31}$ Despite this declared commitment, HaMoked encountered attempts to expel people who had moved to the West Bank before the stipulated date. ${ }^{32}$

According to data submitted by the state to the $\mathrm{HCJ}$, some 3,000 people moved from Gaza to the West Bank after the date stipulated, and they all now live under threat of expulsion. In some cases, their children were also registered as residents of the Gaza Strip, despite residing in the West Bank. Israel does not have an estimated number of these children. ${ }^{33}$

The state's commitment not to expel people who have been living for years in the West Bank does not include changing the address registered in their ID cards. Therefore, they are still registered as Gaza residents. Persons wishing to update their registered address must submit a separate request. If granted, they receive temporary permits only and must wait many years until their address is updated, if at all. COGAT's new procedure, published in July 2013, states that persons who moved to the West Bank before the Disengagement and live there with periodically renewed permits can request to have the fixed period for updating their registered address reduced from seven years to three. ${ }^{34}$

In March 2011, Israel announced that, as part of a diplomatic gesture of goodwill towards the Palestinian Authority, it had decided to retroactively approve an address update for 5,000 Palestinians living in the West Bank, whose registered address was in the Gaza Strip. Of these, some 3,300 had entered the West Bank by

\footnotetext{
$30 \mathrm{HCJ} 6685 / 09$, Kahouji et al. v. Military Commander of the West Bank, response on behalf of the Respondent, 18 November 2009, parags. 25, 28.

31 HCJ 4019, HaMoked v. Military Commander of the West Bank et al., ruling, 21 April 2013.

32 See, for example, HCJ 391/10, Abu Jazar et al. v. Military Commander of the West Bank, where the state objected to the applicant's returning to Gaza, although he had relocated there in 2000, on the grounds that he was unmarried and had no family ties there; HCJ 4976/13, Abu Wadi et al. v. Israel Prison Service et al., where the state intended to release to Gaza a prisoner convicted of illegal presence in the West Bank, as his address had not been updated, and despite the fact that he had moved to the West Bank prior to 2005. 33 HCJ 2088/10, HaMoked v. Commander of the West Bank et al., notice on behalf of the Respondents, 31 January 2012, parags. 7-9.

34 Article 15 of the procedure; see footnote 29 above.
} 
the secure passage before the year $2000 .{ }^{35}$ Later, the state expanded this option, once again as part of a diplomatic gesture of goodwill, to include anyone who had moved to the West Bank before the end of 2007. ${ }^{36}$ To date, only some 2,450 residents and an accompanying 1,440 minors have had their address-change approved as part of the gesture, after many months of processing. ${ }^{37}$ However, for more than a year now - at least, in the cases that HaMoked is handling address changes have not been approved and the state sends applicants to undertake the grueling "relocation request procedure".

Israel's refusal to formally change the addresses of Gazan Palestinians who have moved to the West Bank, along with its policy of sending those who moved to the West Bank after 2005 back to Gaza, has created a reality in which couples who do not share a registered address face three options: live together in the West Bank in constant fear of expulsion, relocate to Gaza, or live apart.

\section{Illustrative Cases}

\section{Fear of expulsion realized}

O.A. was born in the Gaza Strip in 1987. When he was four years old, he moved with his parents and eight siblings to the West Bank, but his registered address was not updated (in fact, the addresses of only two of his siblings were updated after the move). As an adult, he tried to change the address registered in his ID card to his home address in the West Bank, but Israel disallowed it.

On 4 February 2006, when he was 19, O.A. happened to be arrested by the police. He was deported and sent back to the Gaza Strip in the middle of the night, with only the clothes on his back. O.A. was fortunate enough to find shelter with his uncle, but the sudden separation from his family and his daily life took its toll, and his health began to fail.

On 28 June 2006, HaMoked petitioned the HCJ demanding that O.A. be allowed to return to his family at once. ${ }^{38}$ The state chose not to argue its case before the court and allowed him to return home to the West Bank. ${ }^{39}$

35 HCJ 9084/10, Khallu et al. v. Military Commander in the West Bank et al., preliminary response on behalf of the Respondents, 16 March 2011, parag. 4.

36 Letter to Adv. Roy Hartman of Gisha (Israeli NGO "Gisha - Legal Center for Freedom of Movement") from Major Nir Keidar, head of the Economic and Humanitarian Section, International Law Department at MAG Corps Headquarters, 23 July 2012.

37 See footnote 33 above, parag. 10.

38 HCJ 5463/06, Effendi et al. v. Military Commander in the West Bank et al.

39 Ibid., notification of settlement and consented request to cancel petition, 4 July 2006. 
M.K. was born in the Gaza Strip and moved to the West Bank in 2006 with a permit to enter Israel issued him by the military. Since then, he has been living and working in Hebron and has married a resident of the city. The couple has two children.

On 19 August 2009, M.K. was arrested at an army checkpoint near Ramallah and transferred to the Etzion temporary detention facility. The next day, HaMoked learned that the military intended to send him back to Gaza, based on his address as listed in the population registry, and petitioned the $\mathrm{HCJ}$ that same day to try and prevent the expulsion. ${ }^{40}$

The state requested that the petition be rejected, on the grounds that M.K. was living in the West Bank illegally. However, it agreed to have M.K. released pending a decision, subject to a 30,000 NIS [approximately 8,600 USD] security deposit. $^{41}$

The deliberations in M.K.'s case were postponed until a ruling in the petition of principle that HaMoked had filed regarding forcible transfer to Gaza based on registered address. In December 2011, M.K.'s address was updated in the registry as part of the diplomatic gesture of goodwill. Consequently, the state returned his deposit and HaMoked cancelled the petition. ${ }^{42}$

\section{Living apart: A nuclear family torn between Gaza and the West Bank}

Maisoun Haj 'Ali and her husband Ibrahim, both born in the Gaza Strip, have four children. In 2008, Ibrahim moved to the West Bank for work, due to the scarcity of jobs in Gaza. In 2010, his address in the population registry was updated to his home address in the West Bank. He filed a request to have his family come live with him in the West Bank, but received no reply. Maisoun filed a request to visit her husband in the West Bank and was refused by the Office for Civilian Affairs on the Palestinian side, who explained that her request would not be granted as there were no humanitarian grounds for it. Maisoun Haj 'Ali related how her children feel, growing up without their father:

I'm raising the children alone, without their father by my side. I suffer, because the children talk about him every day, asking when we'll go and live with him.

40 HCJ 6685/09, Kahouji et al. v. Military Commander in the West Bank et al.

41 Ibid., notice on behalf of the Respondent, 27 August 2009.

42 Ibid., ruling, 16 May 2012. 


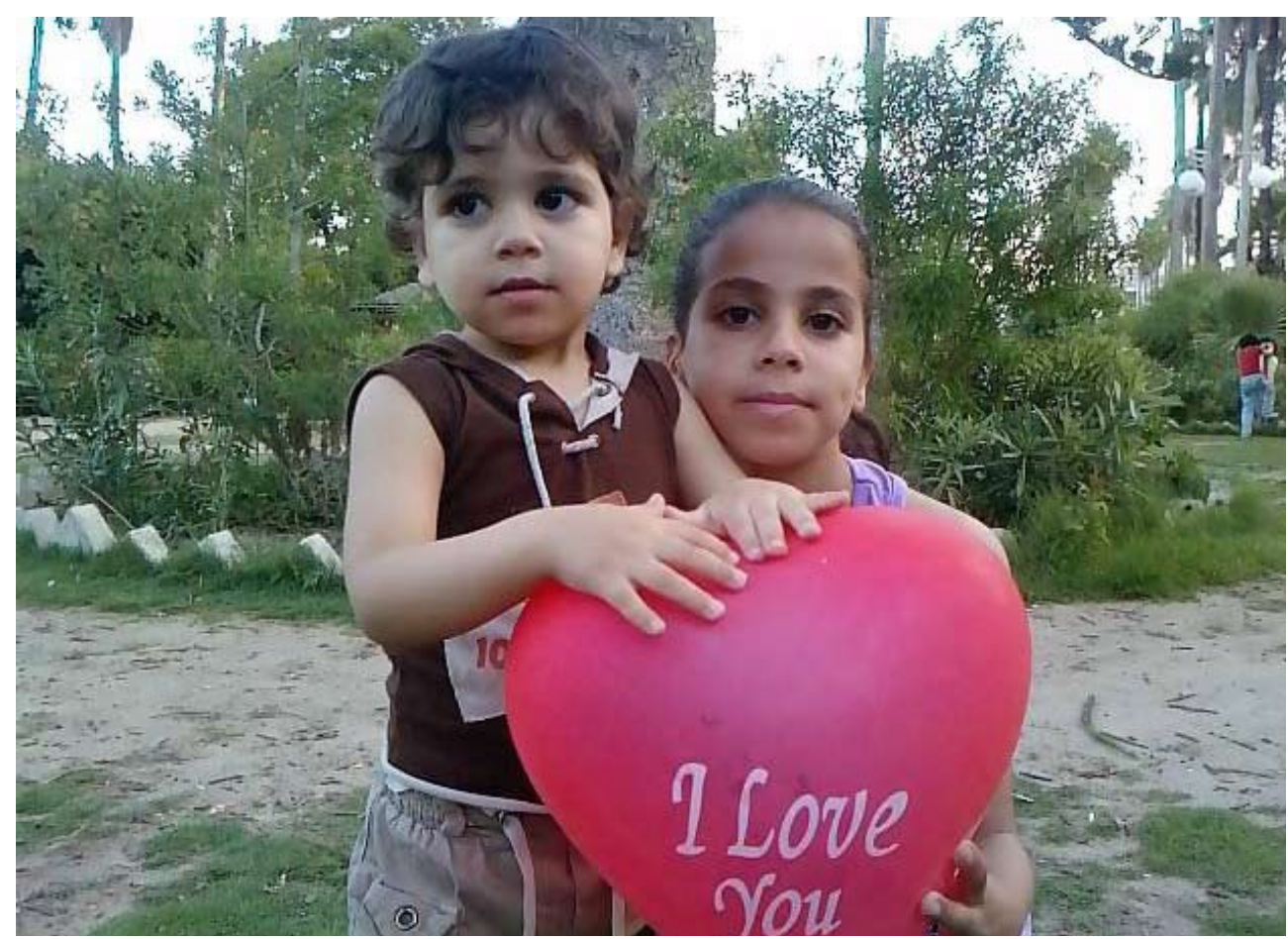

Inas and Rami Haj 'Ali, two of Maisoun and Ibrahim's children. Photo courtesy of the family.

They always ask about their father and say that they want to see him every day, to go out with him and play with him, especially on special occasions.

When my children see their uncles with their children, they ask me : "Why isn't Dad with us, like our cousins who sit with their parents and play with them?" They always feel lonely and that they're missing something and sometimes they feel afraid, because their father isn't with them. I'm in a constant state of tension and worry because my husband isn't with me. I suffer because my children are suffering, since they need to live with their father. We live in hope that our suffering will end, that we'll move in with my husband, stop the telephone calls, and all live together.

The family succeeded in meeting only when Ibrahim's mother passed away and he was given a permit to enter Gaza for several days. Maisoun Haj 'Ali described the happy meeting, mingled with mourning:

Our emotions were mixed. We felt sad because his mother died before he had a chance to see her and because of the bereavement. We were happy because he came to Gaza. We met and lived together for a week. Our children were very happy. They sat with him all the time and asked to eat and drink with him 
and go out with him. We had such a beautiful week. It lasted until Monday, the $25^{\text {th }}$ of March, 2013, when he went to Erez Checkpoint to go back to the West Bank. He found out that the checkpoint was closed because of a high holiday. When he checked with the Palestinian DCO, he was asked to come there on Wednesday, the $27^{\text {th }}$ of March. When he came back home, we were all happy because my husband would get to stay with us for two more days. During those two days, my children bought cookies and celebrated having their dad around. He spent the next day with our children. We felt happy with him. ${ }^{43}$

\section{Soccer player on national team: Choosing between family life and livelihood}

A special article in COGAT procedure allows Palestinian soccer players to travel from Gaza to the West Bank for practice and matches. ${ }^{44}$ The procedure applies only to the players themselves and not to their families. Within that framework, Suleiman 'Obeid, who was born in Gaza and plays on the Palestinian soccer team, moved to the West Bank on 23 June 2008. His wife and two young children remained in the Gaza Strip. 'Obeid told B'Tselem that Israel makes the players'

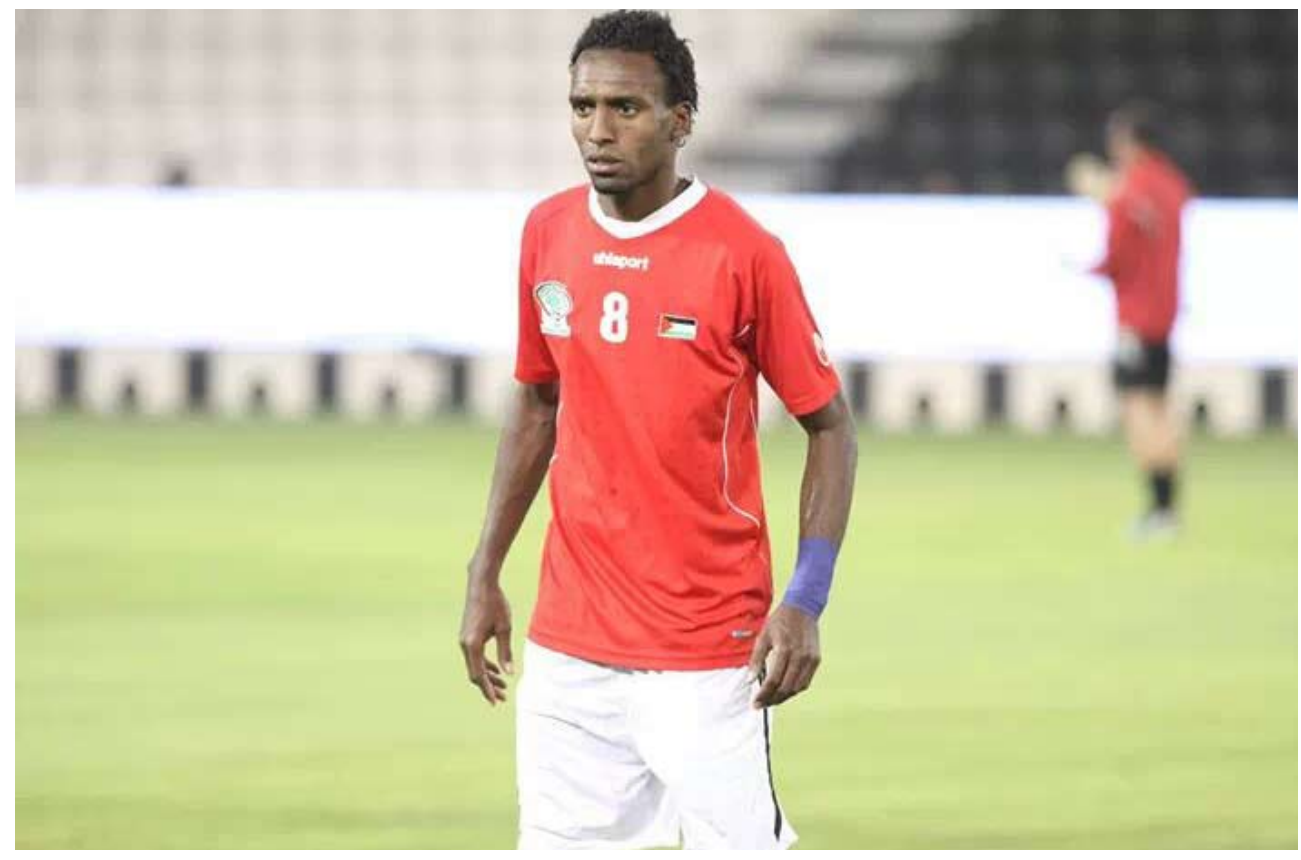

Suleiman ‘Obeid. Photo courtesy of the family.

43 Testimony taken by Muhammad Sabah on 4 April 2013.

44 "Policy Regarding Movement of Persons Between Israel and Gaza", 5 May 2011, Article 15a. For the full policy, see http://www.cogat.idf.il/Sip_Storage/FILES/3/2533.pdf (in Hebrew). 
lives very difficult, and the permit issued him to move to the West Bank applies only one way: If he goes back to Gaza, he will not be able to return to work in the West Bank. Even when his mother fell ill, in the summer of 2011, his request to visit Gaza was denied, and he did not see her before she died. He is allowed to travel abroad through Allenby Bridge only to play in soccer matches. 'Obeid described the difficulties of his daily life:

Wanting to hug your baby and play with him, or when you think about sleeping with your wife or having more kids. These are basic needs that are a given for every person or husband. You can't do that because Israel doesn't want you to do that. It's a tough situation that's also tough to describe.

One thing that comforts me a bit is contact with my family on the phone or through the Internet every day. It's not an exaggeration to say that I try to use every free minute or second that I have to talk to my wife or my little kids. Every phone call or contact that we have, I feel pain, I feel heartbroken, and I just really want to hug them. What can I do? Your eyes can see but your hands can't touch.

I'm not the only one suffering like this, but I suffer doubly because I'm married. There are 25 players like me from Gaza, who came to the West Bank under work agreements with the clubs and the Palestinian team. They came here at different times over the course of two years - 2007 to 2008. Many of them haven't adjusted to living like this, to being unable to see their families and to the difficulty of getting from the West Bank to Gaza and back again. Seven players went back to Gaza and now live with their families. The rest live under the same tough conditions as me. On top of it all, most of them have been allowed to change their address to the West Bank, except for three players. I'm one of the three.

Changing your address means a lot of things. Mostly, if my listed address will be in Ramallah, I'll be able to travel from Ramallah to Gaza through Jordan and Egypt whenever I want, like any West Bank resident. ${ }^{45}$

On 13 May 2013, 'Obeid decided to return to the Gaza Strip to live with his family there, thereby giving up being a player on the Palestinian national soccer league. 


\section{B. Visits by Gaza residents to the West Bank}

\section{Procedure}

The criteria allowing travel between the Gaza Strip and the West Bank for visits are very strict, limiting the possibility of Gaza residents to visit their loved ones in the West Bank. Permits for this kind of travel are given for two reasons only: visiting a gravely ill first-degree relative at death's door or one who requires prolonged hospitalization, and participating in a wedding or a funeral of a firstdegree relative. These permits include the children of the primary applicant, if they are under the age of six. ${ }^{46}$ The processing time of such requests varies, and if a request to attend a funeral is submitted on the day of the funeral itself, not all family members always get the permit in time.

For the last five years, Israel has not permitted family visits for Muslim holidays. Christian residents of the Gaza Strip are allowed, under COGAT procedure, to visit Israel and the West Bank during Easter - and, in April 2013, Israel permitted some 500 such residents under the age of sixteen or over the age of 35, who have security clearance, to enter Israel and the West Bank to visit relatives and take part in festive rituals. ${ }^{47}$

\section{Illustrative Cases}

\section{Stepfather not considered first-degree relative}

A. is a resident of the Gaza Strip whose parents divorced when he was twelve years old. He stayed with his mother, who remarried two years later. Her husband acted as A.'s father and was a full partner in raising him. A.'s stepfather was a senior member of the Palestinian Authority and was forced to move to the West Bank in 2008, after Hamas took control of the Gaza Strip. His wife joined him there, and the Civil Administration changed their address in the population registry to the West Bank, as it did for other Palestinian Authority officials who fled Gaza then. A., who was 25 years old at the time, was close to finishing his

46 See footnote 44 above, Articles 3-5a.

47 COGAT, "COGAT Order - Status of Permits for Palestinians to Enter Israel, to Travel Abroad and to Cross Between the West Bank and the Gaza Strip" (21 April 2013): detailed status of permits in Gaza, Article 17, and detailed status of permits for travel between Gaza and the West Bank, Article 21(9)1:

http://www.gisha.org/UserFiles/File/LegalDocuments/FOIA-travelcriteria/status/2013/21.04.13.pdf (in Hebrew). 
pharmacology studies at a university in Gaza, and therefore did not move to the West Bank with his parents. After graduation A. stayed in Gaza and worked as a pharmacist.

In February 2012, A. applied to the Palestinian Committee for Civilian Affairs and asked to arrange a visit to the West Bank, as his stepfather's health was deteriorating. He was told that the Committee could not even forward the request to the Israeli side, as the relative in question is a stepfather. HaMoked applied to the authorities on his behalf but, four days later, on 3 March 2012, A.'s father died before any response was received. The next day, A. applied to the Palestinian Committee for Civilian Affairs to coordinate traveling to the West Bank to attend the funeral; at the same time, HaMoked applied on his behalf to the humanitarian hotline at the Gaza DCO. Neither application was answered in time and A. missed his stepfather's funeral. His mother was left alone at the funeral, as she has no relatives in the West Bank and the couple had no joint children.

As A.'s request received no response, HaMoked petitioned the $\mathrm{HCJ}$ on 7 March 2012. ${ }^{48}$ The next day, HaMoked received a letter from the Erez DCO summoning A. for an appointment on 13 March 2012. The meeting was finally held on 29 March 2012, after repeated delays by the authorities: A. was asked why he insisted on going to the West Bank even after the mourning period was over, and was required to promise that he would return to the Gaza Strip. On 1 April 2012, more than a month after HaMoked's request was filed and more than a month and a half after he first applied for a permit to visit the West Bank, A. was given a five-day permit to visit his mother.

\section{Meetings with relatives, mostly in times of distress}

Nibal Mghari, born in 1967 in Jenin, has lived with her husband and children in the Gaza Strip since 1993. In the first years of her marriage, she was able to regularly visit her family in the West Bank. However, since 2000, she has been given permits to do so only in extreme circumstances. In 2002, she was issued a permit to travel to the West Bank in order to visit her father, who had suffered a heart attack. In early 2004 and again in late 2004, she gave birth to two stillborn babies; despite her difficult circumstance, requests to visit her filed by family members in the West Bank were denied. It was only in May 2005 that her parents 
succeeded in visiting her at home for five days. In August 2005, when Mghari's father was hospitalized in Jordan, she traveled to see him via Rafah Crossing and Egypt. After that, she was not given another permit to visit her sick father. When he died, on 10 December 2005, she received no reply to a request she filed to travel to the West Bank, and she was unable to be with her family there during the mourning period. Mghari described her feelings:

My uncles on my mother's side came from the United States when they heard about my father's condition, while I, who live in the Gaza Strip - so close, compared to the United States - couldn't see my father because Israel didn't even respond to my request.

On 3 June 2007, Mghari learned that her sister, who lived in Jenin, had cancer. She filed requests to receive a permit to visit her - but, although she went to the DCO office every single day to try and move the process along, she was only given a permit when her sister died, five months later. Even then, Mghari was detained at the exit from Erez Crossing and reached Jenin only after the funeral had ended. She related to B'Tselem what happened:

I was detained at Erez Checkpoint and didn't attend my sister's funeral and didn't say goodbye to her before she was buried. I reached Jenin towards nightfall and immediately went to the cemetery. I was devastated and couldn't comprehend my sister's death. I didn't see her before she died, but I spoke to her on the phone almost every day. My family and I were in shock, but the fact that I was there made it a bit easier for my mother. Two months after my sister died, I went back to Gaza...

From 2008 until November 2011, I wasn't given a permit to visit my family. That means that I didn't see my family for four years. I submitted requests to have a permit issued with the Committee for Civilian Affairs, especially for visits during the holidays and family events, but it didn't help.

My last visit was in November 2011. I was given a permit for four days only, during which I visited my family and checked in on my mother. Meeting my family was like a wedding. A lot of relatives and neighbors stood waiting for me on the road. Some of them had cameras and they were taking photos of me. Lots of relatives and brothers and sisters gathered in our family's house to congratulate me. Since then, I haven't been given another permit. My husband goes regularly to the Committee to inquire about our requests, and they tell him that there are no permits to visit the West Bank. ${ }^{49}$ 
All of Mghari's visits to her family in the West Bank were alone; her husband and children have not had the chance to meet her family. Mghari's mother, Fatmah Abu 'Issa, told B'Tselem how hard it is for her to be separated from her daughter in Gaza:

I pray that I won't die before I get to see Nibal and her children and husband in my house. I don't want Nibal to come to the mourning tent they'll put up for me. I don't want Nibal's visits to Jenin to be only in mourning. ${ }^{50}$

\section{High Court petition to fulfill right to visit as set out in COGAT procedure}

R. S., who has lived in the Gaza Strip since she got married, has had to petition the HCJ twice in three and a half months in order to attend the weddings of her brother and her sister in the West Bank. On 14 May 2012, she submitted a request through the Committee for Civilian Affairs to leave Gaza with her husband and two young children, so that they could attend her sister's wedding in the West Bank on 27-28 June $2012 .{ }^{51}$ As she received no response, HaMoked filed a petition with the $\mathrm{HCJ}$ on 19 June $2012 ;{ }^{52}$ four days later, they received the permit..53 On 12 October 2012, R.S.'s brother was supposed to wed. HaMoked applied to the Gaza DCO on 9 September 2012 so that a permit would be issued for R.S. and her young son. ${ }^{54}$ No response was received, and HaMoked petitioned the HCJ on 30 September $2012 .{ }^{55}$ Again, the permit was granted four days after the petition was filed. ${ }^{56}$

\section{Passage from the West Bank to the Gaza Strip}

While Israel makes every effort to prevent Palestinians who live in the Gaza Strip from moving to the West Bank and settling there, as far as the reverse direction is concerned - moving from the West Bank to the Gaza Strip - its policy is quite the opposite. The procedure for relocating from the West Bank to Gaza states that "the basic assumption is that a resident of the West Bank may

50 Testimony taken by 'Atef Abu a-Rub on 30 April 2013.

51 HaMoked sent letters on the matter to the public complaints department at Erez DCO on 30 May 2012

and 7 June 2012.

$52 \mathrm{HCJ} 4808 / 12$, Sweir et al. v. Military Commander in the West Bank et al.

53 Letter to HaMoked from the public complaints service center at Gaza DCO, 23 June 2012.

54 Letter to HaMoked from the public complaints service center at Gaza DCO, 9 September 2012.

55 HCJ 7113/12, Sweir et al. v. Military Commander in the West Bank et al.

56 Letter to HaMoked from the public complaints service center at Gaza DCO, 3 October 2012. 
submit a request to permanently settle in the Gaza Strip for any need that is considered humanitarian (usually family unification)". This markedly contrasts the procedure for relocating from Gaza to the West Bank, which states that marriage does not constitute a humanitarian criterion. According to the first procedure, requests will be granted on condition that the applicant sign a document that includes a declaration of intent to settle in Gaza permanently and the applicant's understanding that there is no possibility of returning to the West Bank, even for visits, except in unusual humanitarian circumstances. ${ }^{57}$

COGAT procedures list two types of humanitarian circumstance: 1. Visiting a gravely ill first-degree relative in danger of death or prolonged hospitalization. The age of the patient is a factor in such a case. 2. Participating in a funeral or a wedding of a first-degree relative. The procedures do not address the issue of minors accompanying the applicant..$^{58}$

HaMoked criticized this policy in a petition filed to the $\mathrm{HCJ}$ demanding that a West Bank resident and her children be let into Gaza to be with the father of the family, who was among the Church of the Nativity deportees. ${ }^{59}$ Among other things, HaMoked argued that making the crossing contingent on signing a commitment to settle in Gaza constitutes unacceptable pressure based on exploiting the family's distress. This stipulation is, in effect, forced transfer of a population under occupation from its place of residence - a step that contravenes international law. HaMoked further argued that the state's distinction between a short visit (allowed only in exceptional humanitarian cases) and permanent relocation to Gaza (which the state agreed to allow) is incompatible with the complex reality of a family unit. The court adopted the state's position and rejected the petition. ${ }^{60}$

According to data that COGAT provided to B'Tselem, 492 requests were filed in 2012 by West Bank residents wishing to visit Gaza, of which 166 were approved. The remaining 326 requests were denied on various grounds, including criteria not met, documents not submitted, or security concerns. Six people signed a commitment never to return to the West Bank, following which they were issued a permit to relocate to the Gaza Strip. ${ }^{61}$

\footnotetext{
57 "Procedure for West Bank Residents Settling in Gaza", December 2010, Articles 1b, 3b. For full procedure, see http://www.hamoked.org.il/Document.aspx?dID=Documents2212 (in Hebrew).

58 See footnote 44 above, Article $10 \mathrm{~b}$.

59 HCJ 1583/10, Abu Hamida et al. v. Military Commander of the West Bank et al.

60 Ibid., ruling, 25 March 2010.

61 Letter to B'Tselem from COGAT Spokesperson Major Guy Inbar, 4 August 2013, in reply to B'Tselem's request for information under the Freedom of Information Act, 13 March 2013.
} 
In sum, the harsh limitation on issuance of permits to cross from the West Bank to the Gaza Strip results in people managing to meet with their loved ones only under the extreme circumstances of a serious illness, a wedding, or a death in the family.

\section{Illustrative Cases}

\section{Request denied on grounds that medical condition not serious enough}

On 30 April 2013, A.A., a resident of Bethlehem, filed a request for a permit to visit her sick mother in the Gaza Strip, attaching medical documents attesting to her mother's condition. On 21 May 2013, she received a reply noting that "after reviewing the request, the military commander decided not to approve it, as the documents attached to the resident's request do not indicate imminent death justifying issuance of a permit to enter Israel in order to travel to the West Bank." ${ }^{62}$ Two and a half weeks later, on 9 June, the mother passed away, and A.A. was issued an entry permit to attend her funeral.

\section{Delays in cases requiring a speedy response}

\section{Request to visit patient approved only after patient died}

M.A., a resident of Nablus, wished to visit his 88-year-old mother in the Gaza Strip, who was hospitalized after suffering a stroke and being diagnosed with a spinal tumor. On 26 October 2011, he submitted to the DCO in Nablus a request for a permit to visit Gaza. As he received no response, HaMoked applied on his behalf on 30 October 2011, appending medical documents supporting the request. ${ }^{63}$ The next day, the Civil Administration notified HaMoked that the request was being processed and that the urgency of the matter was clear. ${ }^{64} \mathrm{On}$ 3 November 2011, M.A.'s mother passed away, before any response to his request was received. The very same day, HaMoked petitioned the $\mathrm{HCJ}$ requesting that M.A. and his wife be allowed to travel to Gaza; the permit was granted even before the court session that was scheduled later that day. ${ }^{65}$

62 Letter to HaMoked from Second Lieut. Bar Akuka, Public Complaints Officer at the Civil Administration, 21 May 2013.

63 Letter from HaMoked to the Civil Administration, 30 October 2011.

64 Letter from Lieut. Amos Wagner, Public Complaints Officer at the Civil Administration, 31 October 2011.

65 HCJ 8117/11, Abu Sata et al. v. Military Commander of the West Bank et al. 


\section{Mourning necessitates immediate response}

Najah Hamdan was born in the Gaza Strip and has lived in Bethlehem for 33 years. She told B'Tselem how she was denied the possibility of visiting both her parents, when they were ill. The permits to attend their funerals were also issued late, and the funerals were held without her:

About nine years ago, my father was hospitalized for a month. His condition was serious. My brothers sent me medical reports to submit together with my request for a permit. The permit was issued too late, a day after my father died.

I came to Gaza after I hadn't been there for many years, missing my family. My father had already been buried, and I didn't get the chance to see him for the last time and say goodbye. When I saw my mother and brothers standing in the mourning tent, I broke down in tears, because it was the first time l'd seen them in years, and it was in the mourning tent for my father, who had passed away while I was missing him. My brothers and I went to say goodbye to him at the cemetery.

Every time I remember that situation of standing next to my father's grave and visiting my family, I cry, especially when I was in that situation again, when my mother died two years ago. She got sick and was in hospital for three months. During that time, I filed requests to get a permit to visit Gaza and see her, but I was told that if I went to Gaza, I couldn't come back.

After three months, my mother died. I cried a lot. I didn't get a chance to see her and say goodbye. My brothers filmed my mother in hospital. I saw the tape and it was one of the hardest things I'd ever seen. It was a feeling of bitterness and sadness. It's so hard to see your mother when she's dying and you're not next to her holding her hand and saying goodbye. There's nothing harder than that painful moment. How can you deny a person their chance to see their father and mother and say goodbye to them when they're sick? Something broke inside me. Yes, we're all going to die and we'll all have to go on without the people we love at some point, but we do that after we say goodbye, without someone keeping us from saying goodbye to the ones we love. ${ }^{66}$ 


\section{High Court petition to realize right to visit Gaza in accordance with COGAT procedure}

$\mathrm{H}$. and R. are sisters who were born in the Gaza Strip and both married to West Bank residents. The two had to petition the $\mathrm{HCJ}$ twice to be allowed to enter Gaza to attend their brothers' weddings - in July $2011^{67}$ and in October 2012.68 The petitions were filed after requests submitted by HaMoked received no response for over three weeks. The sisters asked that their children, whose ages range from five to eighteen, be allowed to attend the first wedding with them, but only the five-year-old was given a permit. For the second wedding, they asked to include the 14-year-old son of one of them, but the State Attorney's Office stated that he could not accompany his mother as he was older than six and was not a first-degree relative of the bridegroom. ${ }^{69}$

\section{Open heart surgery - "does not meet criteria"}

S.T.'s sister underwent bypass surgery in the Gaza Strip on 18 March 2013. A week or so before the surgery was set to take place, S.T. filed a request with the Ramallah DCO for a permit to enter Gaza. The authorities did not process the request properly and, as a result, she missed her sister's surgery. First, it was claimed that the sister's ID number did not appear in the medical documents submitted. ${ }^{70}$ After the mistake was clarified, ${ }^{71}$ S.T. was required to resubmit her request to the $D C O .^{72} \mathrm{~A}$ day before the surgery, S.T. was updated by phone that her request had been denied as it failed to meet the set criteria.

On 21 March 2013, HaMoked petitioned the HCJ demanding that S.T. be permitted to visit her sister, who was recovering from the surgery. Two and a half months later, State Attorney's Office required HaMoked to provide it with a medical document describing the sister's current situation, so that S.T.'s request could be considered based on current circumstances. ${ }^{73}$ HaMoked objected

\footnotetext{
67 HCJ 5049/11, Abu Tarabush et al. v. Military Commander of the West Bank et al.

68 HCJ 7161/12, Abu Tarabush et al. v. Military Commander of the West Bank et al.

69 Email sent to HaMoked from Adv. Yitzhak Bart, Assistant to the State Attorney, 10 October 2012.

70 Letter to HaMoked from Second Lieut. Bar Akuka, Public Complaints Officer at the Civil Administration, 11 March 2013.

71 Letter to Second Lieut. Bar Akuka, Public Complaints Officer at the Civil Administration, from HaMoked, 14 March 2013.

72 Letter of response to HaMoked's letter of 14 March 2013, by Second Lieut. Bar Akuka, Public Complaints Officer at the Civil Administration, 14 March 2013.

73 Letter to HaMoked from Adv. Reuven Idelman, Senior Assistant to the State Attorney, 2 June 2013.
} 
on the grounds that the demand was irrelevant, as any request could then be delayed indefinitely until it was no longer considered humanitarian. ${ }^{74}$

In its response to the $\mathrm{HCJ}$, the state claimed that "the operation itself does not endanger the patient's life" and also tried to play down the mistakes that were made in processing S.T.'s first requests. ${ }^{75} \mathrm{At}$ an $\mathrm{HCJ}$ session, the state argued that the request would not have met the set criteria even if those mistakes had not been made, as the matter at hand was a simple operation. Justice Hayut said:

It is very hard to accept that argument. We suggest that this very exceptional case be considered, due to the various malfunctions that occurred in this case... We are very much inclined to issue a court order... You have received material [indicating] that this is a matter of open-heart surgery. If anyone thinks that it a simple operation, then there is a problem with the professional position. ${ }^{76}$

On 27 June 2013, more than three months after her sister's surgery and before the HCJ had ruled in the case, S.T. was issued a permit to visit the Gaza Strip.

This case is the exception to the rule, as S.T. was eventually allowed to visit her sister, even after several months had elapsed. The permit was made possible by petitioning the $\mathrm{HCJ}$, whose justices criticized the clear faults in the way the Israeli authorities had handled the request, primarily the medical opinion that the state presented. In most cases, once the medical case is classified as not serious enough, a sick person's relatives are forced to waive their right to visit him or her.

74 Letter to Adv. Reuven Idelman, Senior Assistant to the State Attorney, from HaMoked, 3 June 2013.

75 HCJ 2204/13, Tawabta et al. v. Military Commander of the West Bank, preliminary response on behalf of the Respondents, 13 June 2013.

76 Ibid., session transcript, 17 June 2013. 


\section{Rafah Crossing}

Recently, the HCJ denied a petition filed by HaMoked regarding passage from the West Bank to the Gaza Strip in order visit a sick mother. The Court stated that "at this time, it is possible to travel from the West Bank to Gaza through Rafah, notwithstanding the inconvenience involved".77 However, Israel's duty to enable free passage between the West Bank and Gaza does not depend on external factors such as whether neighboring countries are willing to allow passage through their territory. Even now, eight years after withdrawing its forces from the Gaza Strip, Israel prevents residents of Gaza from operating an airport or a marine port and forbids them from crossing through Allenby Bridge (between the West Bank and Jordan) or through Ben Gurion Airport in Israel - thereby barring them from realizing their right to freedom of movement. Since Israel does not fulfill its duty, the availability of Rafah Crossing is essential to West Bank residents wishing to visit Gaza, and especially to those who do not meet the strict criteria for permits set by Israel. Israel forbids people whose home address is listed as Gaza in the population registry to enter the West Bank via Allenby Bridge without a special permit. ${ }^{78}$ Furthermore, residents of Gaza who wish to enter Jordan are required to obtain a permit from the Jordanian government confirming its approval of their entry. Therefore, even when Egypt opened Rafah Crossing, residents of Gaza could not visit the West Bank without a permit from Israel.

Opening Rafah Crossing enabled West Bank residents to reach Gaza - via Jordan and Egypt, a route that can take several days in each direction and cost thousands of shekels. By comparison, traveling from the West Bank to Gaza via Israel takes only a few hours. In addition, Rafah Crossing is not open regularly and Egypt can close it at any time. That is what happened in July 2013, and Egypt has limited passage through the crossing ever since.

77 HCJ 5952/12, Abu Meshayeh et al. v. Military Commander of the West Bank et al., ruling, 21 March 2013.

78 See "Procedure for Gaza Residents Crossing at Allenby Bridge", at COGAT website: http://www.cogat.idf.il/Sip_Storage/FILES/8/3528.pdf (in Hebrew). 


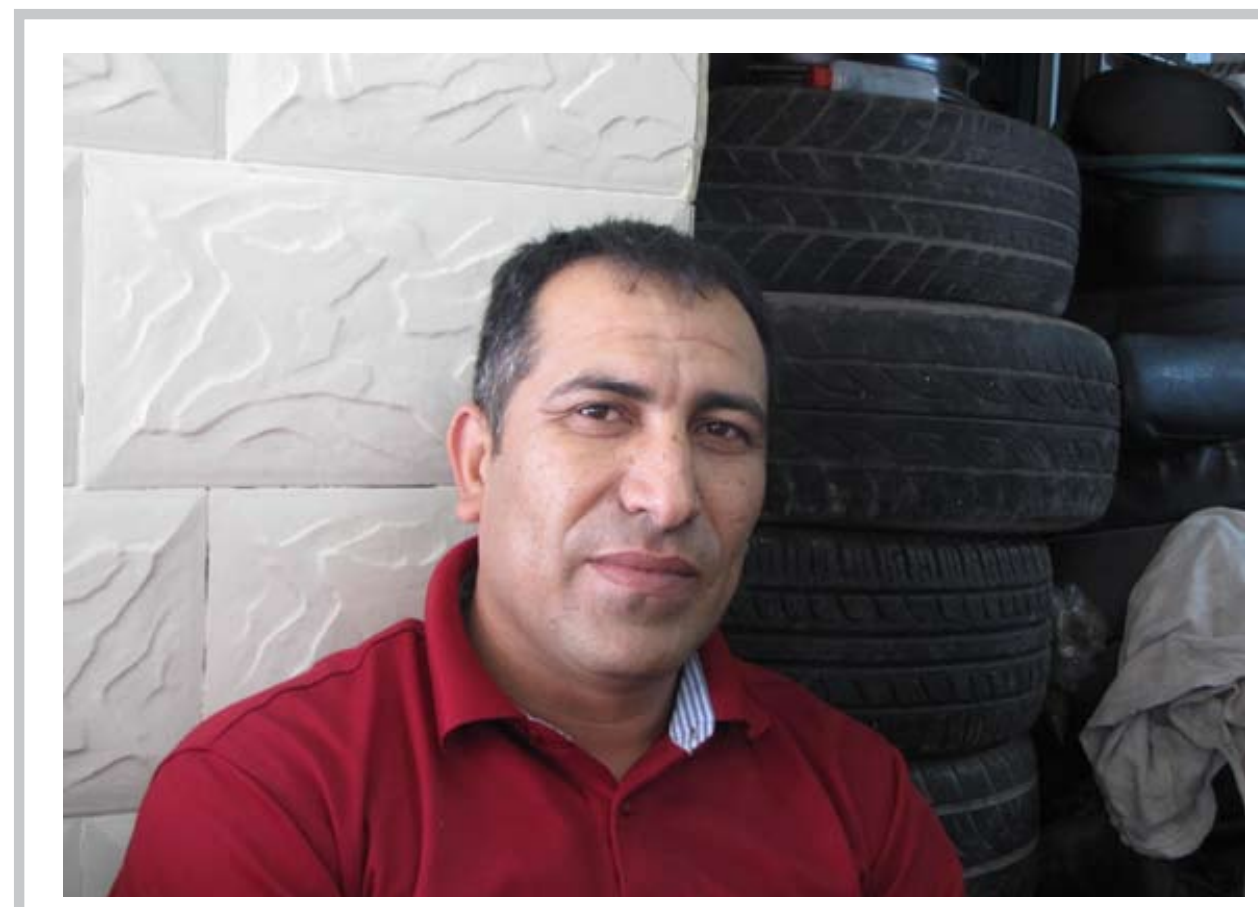

Ahmad Nassar. Photo by Salma a-Deb'i.

Ahmad Nassar was born in the Gaza Strip and has lived in Nablus since 1996 - yet his address was updated in the population registry only in 2012. After twelve years in which he did not see his family, Nassar traveled to Gaza with his wife and children. He went via Jordan and Egypt after the Palestinian DCO informed him that, even if he received an Israeli permit to visit his elderly parents, his wife and children would not. Nassar related the taxing journey to B'Tselem:

At Allenby Bridge, we went through the Palestinian side, then through the Israeli side, then to the Jordanian side, then to the Jordan Bridge and from there to Al-'Aqaba. We were supposed to travel by ship, but before we could board, we had to sleep out on the road because there was no time to book a place in a hotel - I hadn't thought it would take so long to get through the crossings. At 5:00 A.M., the Egyptian ship arrived. There were a lot of people there with a lot of luggage, and I was afraid it would sink. The conditions on board were exhausting. The food was disgusting and my children refused to eat it. The toilets were in really bad shape. 
When we got to the port in Egypt, we waited about six hours for our luggage to arrive. Getting to Rafah took thirteen hours... We got to Rafah Crossing at 5:00 A.M. The crossing only opens at 10:00 A.M., and the Egyptians wouldn't let us in. I refused to go away and told them that we'd been traveling for three days, that the kids were very tired and that we had nowhere else to go. They took pity on us and let us in to a nearby mosque and brought us some food. The heat and the mosquitoes only made it worse for us. At 10:00 A.M., they opened the crossing and we went through. ${ }^{79}$ 



\section{Travel between the Gaza Strip and Israel}

This report does not address the entry of Gazan residents into Israel - which is regularly permitted only to particular groups of merchants and in exceptional humanitarian cases, usually concerning medical treatment. It relates only to Israeli citizens and residents entering and leaving Gaza. As of 1994, when the Palestinian Authority entered the Gaza Strip as part of implementing the Oslo I Accord, any entry by an Israeli citizen or resident into Gaza requires permission from the Israeli authorities.

In 2003, Israel enacted a temporary order barring West Bank or Gaza residents who marry Israelis from receiving legal status in Israel or from being in Israel. ${ }^{80}$ Over the years, exceptions were made to the total ban, enabling some Palestinians to receive temporary status in Israel or temporary permits to be in the country. However, in 2008, Gaza residents could no longer be included in these exceptions to the rule, once the Israeli government declared the Gaza Strip an area where activity "that may endanger Israeli security" is taking place, and therefore no permits to live or stay in Israel were to be given to persons living in Gaza or whose home address is listed as Gaza. ${ }^{81}$ Accordingly, couples where one partner is a Gaza resident and the other a resident of Israel cannot live together in Israel. They must either live in Gaza or live apart.

For these couples, living together in Gaza is governed by the "split family procedure". The procedure requires the Israeli partner to get a permit for every entry to Gaza. The permits must be renewed every few months. Once they are adults, Israeli children of Israeli citizens or Israeli residents living in Gaza must leave their family in Gaza and move to Israel. Israeli families with relatives in Gaza can visit them only in exceptional humanitarian cases, concerning first-degree relatives only. 
According to COGAT, on 9 July 2013, 278 Israelis over the age of sixteen and another 157 Israelis under 16 were in the Gaza Strip under"split family procedure" or for visits. COGAT informed B'Tselem that its computer program does not provide a quantifiable breakdown that distinguishes Israeli citizens from Israeli residents (Palestinians living in East Jerusalem with blue ID cards) ${ }^{82}$

\section{A. "Split family procedure" - Israeli citizens or residents married to Gaza residents}

\section{The procedure}

In accordance with a demand made by HaMoked in the early 1990s, Israel formulated a procedure in 1995 enabling people from "split families" to live with their family in Gaza while maintaining ties with their relatives in Israel. ${ }^{83}$ The procedure is still in place. Most Israelis who live in Gaza or visit it under the procedure are women. The rest of the following section will, therefore, discuss women. In all cases HaMoked handled of Israeli men married to Gaza residents, the men chose to live in Israel and periodically visit Gaza.

According to the procedure, an Israeli spouse of a Gaza resident may submit a request to enter Gaza, attaching the required documents, to the "Israelis' Office" of the DCO at Erez Crossing. The request to enter can be for visiting the Gazan spouse, if the couple lives apart; or, if the couple live together in Gaza, it might be a request by the Israeli spouse to return home to Gaza after a visit in Israel. Requests are checked on an individual basis by the DCO and security officials, who can deny the request on security grounds relating to the applicant, to her spouse or to their extended family. ${ }^{84}$

If the request is granted, the woman is given a permit for a limited amount of time, subject to changes based on the security situation. At first, permits were issued for three months; when the second intifada started, permits were limited to one month only; at present, permits are issued for six months at a time..$^{85}$ Women who wish to remain in the Gaza Strip after the permit expires

82 Letter to B'Tselem from Major Guy Inbar, COGAT Spokesperson, sent on 10 June 2013 in reply to B'Tselem's request for information under the Freedom of Information Act, sent on 2 April 2013.

83 Letter to HaMoked from Judicial Officer Ron Shalev, Assistant to the Legal Advisor in Gaza, 12 September 1995.

84 See, for example, HCJ 6409/08, 'Azbeh et al. v. OC Southern Command et al., consented request to cancel petition, 24 November 2008.

85 Letter from HaMoked to the Legal Advisor in Gaza regarding shortening permits' validity from three months to one, 24 January 2002. See http://www.hamoked.org.il/items/8624.pdf (in Hebrew). 


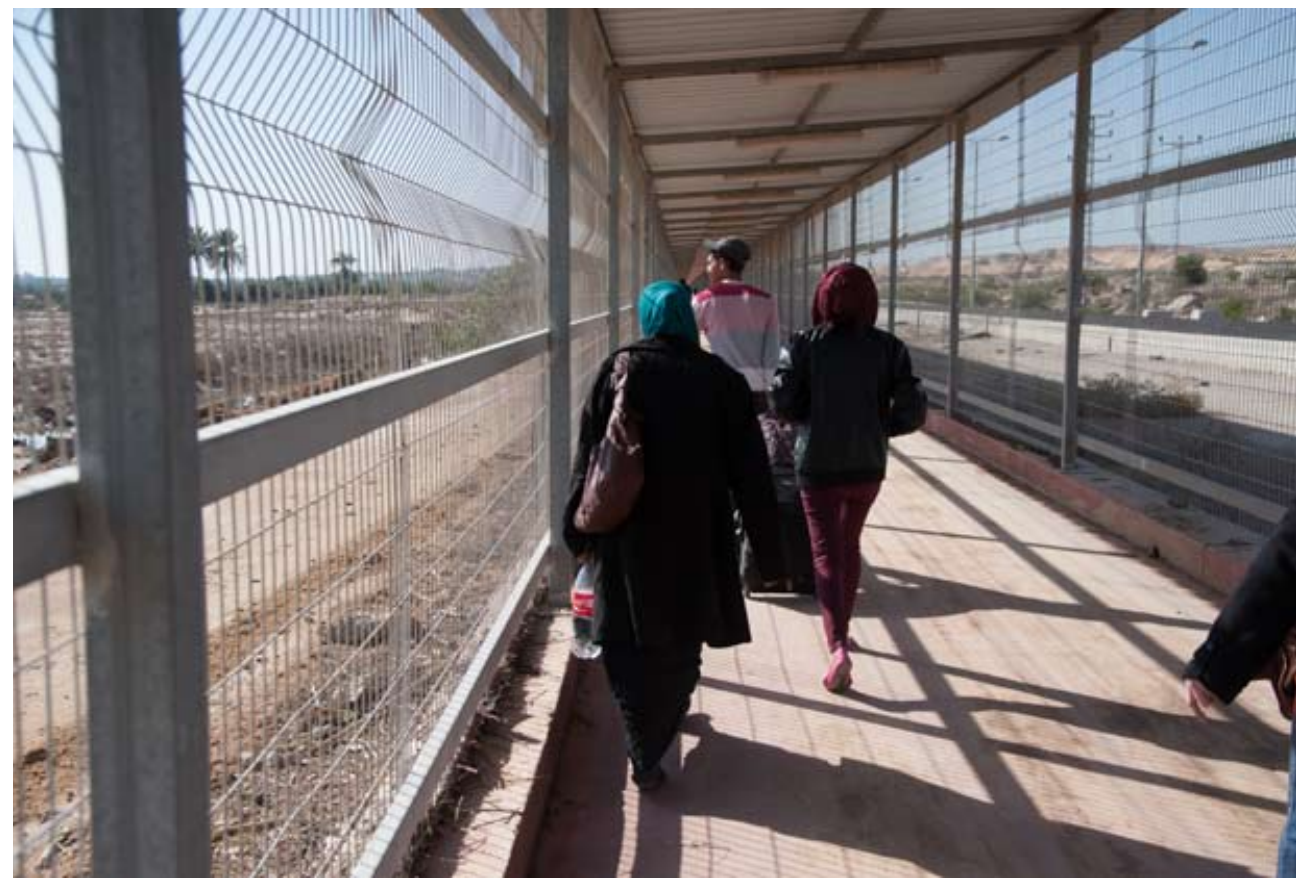

Erez Checkpoint. Photo by Ryan Rodrick Beiler, Activestills, 18 December 2013.

must come in person to Erez Checkpoint shortly before the permit's expiration date. $^{86}$

Since these women are citizens or residents of Israel, they are entitled to enter Israel via Erez Checkpoint whenever they wish. However, once they do so, their permit for Gaza expires - and they have to submit a new request to re-enter Gaza.

Women who remain in Gaza without renewing their permits encounter difficulties when they request a permit to re-enter Gaza after having been in Israel. Usually, when these women arrive at Erez Checkpoint in order to cross into Israel, they are taken for police interrogation on suspicion of having breached a majorgeneral's order prohibiting Israelis from entering the Gaza Strip. In several cases, women were even prosecuted on those charges. ${ }^{87}$ At present, there are women who have been in Gaza for several years with invalid permits, and refrain from leaving for fear of repercussions - either being denied a permit to re-enter Gaza

86 Letter to HaMoked from Meital Zarihan, Assistant to the Legal Advisor for Gaza, 9 November 2004, parag. 8. See http://www.hamoked.org.il/items/8623.pdf (in Hebrew).

87 Ibid., parag. 11. 
after having been in Israel, or having their status as Israeli residents revoked, if they are Palestinians from East Jerusalem. ${ }^{88}$

During the second intifada, Israel suspended the "split family procedure" several times, for periods ranging from several days to several weeks. As long as the procedure was suspended, the DCO did not renew the permits of women who remained in Gaza nor did it issue new permits for those wishing to enter Gaza from Israel. However, in a notice provided to the HCJ on 27 August 2004, the state claimed that the procedure was operating as usual despite the intifada. ${ }^{89}$ Since that notice was given, the procedure has indeed operated without interruption. At present, even when Erez Checkpoint is closed to Palestinian travel due to securityrelated attacks, Israeli spouses of Gaza residents are usually allowed passage. ${ }^{90}$

The children of Israeli citizens are entitled to an Israeli citizenship, and have the right to enter their country whenever they choose. However, receiving legal status in Israel depends on their mother registering them with the Israeli population registry. Until then, the military treats them as residents of the Gaza Strip. Registered children automatically receive permits to be in Gaza, when their mothers receive permits, until they are sixteen years old. From that age on, the adolescents are required to get ID cards and pass "security classification" as a prerequisite for entering Gaza. When they reach the age of majority at eighteen, they are no longer considered part of the "split family" and the procedure no longer applies to them. These young adults can no longer remain in Gaza with their families, and their requests for permits to enter Gaza are denied. Also, there is no procedure enabling them to visit their parents and family in Gaza on a regular basis, and they can do so only in exceptional humanitarian cases.

The children of Israeli residents (Palestinians from East Jerusalem) living in Gaza are registered in the Palestinian population registry as residents of Gaza and are not considered Israeli: Receiving residential status in Israel requires proving one's "center of life" is in Israel. Therefore, the "split family procedure" does not relate at all to their entering Israel. When the mothers live in Israel and only

\footnotetext{
88 See pp. 42-43 below.

89 HCJ 10043/03, Abajian et al. v Commander of the IDF Forces in the Gaza Strip, complementary response (no. 2) on behalf of the Respondent, 27 August 2004, parag. 22.

90 See Gisha, Creeping Punishment, May 2013, http://www.gisha.org/UserFiles/File/publications/ Creeping-Punishment/Creeping-Punishment-may2013-eng.pdf; and Gisha, "Military Policy Documents Arranging the Movement of People and Goods in the West Bank and the Gaza Strip", 25 June 2013, http:// www.gisha.org/item.asp?lang_id=en\&p_id=2013, and examples there, including 28 February 2013, 21 March 2013 and 12 May 2013.
} 
visit their spouses in Gaza, the children - who live with their mothers in East Jerusalem - are classified as residents of Israel and must receive permits to enter Gaza for visits with their mothers.

According to figures that COGAT provided B'Tselem, there are currently 425 Israeli men and women - either Israeli citizens or residents of East Jerusalem - married to residents of Gaza. Of these, some 340 are regularly issued permits under the "split family procedure" - either renewal of permits to stay in Gaza or new permits to enter Gaza from Israel.

COGAT did not list the ages of the persons issued permits, nor did it explain why the remaining 85 persons did not receive permits. Therefore, it is not clear whether those persons did not apply for permits, or whether their requests were denied..$^{91}$

\section{Difficulties in implementation of procedure}

Israeli women applying for permits under the "split family procedure" time and again come up against bureaucratic obstacles or claims regarding security clearance, making a normal routine difficult. From 2008 to 2012, HaMoked dealt with approximately 550 applications concerning entry into Gaza from Israel under the "split family procedure".

The major problems that these women encounter are:

A. Receiving a permit to enter Gaza: This is the main obstacle facing Israeli women who live in Gaza. While they can leave Gaza freely, they can only submit a request to return home once in Israel. Requests take many weeks to process, and even longer when there is an escalation in conflict in Gaza. Consequently, many of these women have no choice but to stay in Israel much longer than they had planned to, without knowing when they will be reunited with their spouses and children. The uncertainty involved, and the fear of being separated from their families for a long time - especially if small children are involved - prevent many mothers from attempting to visit their relatives in Israel in the first place.

B. Renewing permits within Gaza: Women who wish to renew their permits to stay in Gaza are required to report in person to Erez Checkpoint. They

91 Letter to B'Tselem from Major Guy Inbar, COGAT Spokesperson, sent on 10 June 2013 in reponse to B'Tselem's request for information under the Freedom of Information Act, sent on 2 April 2013. 
must also contact the "Israelis' Office" in the Gaza DCO in advance, to ensure that their permits can be renewed. However, phone calls are not always answered at the office, and the facsimile machine sometimes breaks down. In other instances, women have been erroneously informed that they may come to Erez Checkpoint to renew their permits but, upon arrival, soldiers refused to let them through and they had to return home without having the permit renewed. Moreover, some women cannot come to the checkpoint in person at a given time - for instance, if they are ill or recovering from childbirth.

C. Restrictions on children of Israeli residents (East Jerusalem) entering Israel: The "split family procedure" does not apply to the children of Israeli residents, as their legal status is not automatically transferred to their children. If the children live in Gaza, they are registered in the Palestinian population registry. Until 2008, Israeli residents' children under the age of sixteen could enter Israel with their mothers without a special permit. In 2008, COGAT began requiring that the children get their own permit to enter Israel. At first, these permits were issued relatively quickly. ${ }^{92}$ However, in 2010, COGAT began forbidding minors over six years old from entering Israel with their Israeli resident mother, in a procedure similar to the one for Gaza residents who receive a permit to enter Israel for humanitarian purposes. ${ }^{93}$ The Beersheba District Court rejected a petition filed by HaMoked on the matter. ${ }^{94}$ Now, individual permits are issued for minors under six years of age to enter with their mothers. Some of the permits are issued for very short periods - less than the time that it takes their mothers to renew their permits to enter Gaza. In these instances, there is no choice but to have the children remain in Israel illegally until their mother's re-entry into Gaza is arranged. Children over the age of six are denied outright the option of joining their mothers on visits to Israel.

D. Lack of security clearance: Receiving a permit to enter Gaza depends on receiving security clearance for both partners and for their families. If authorities cite security concerns regarding any one of those persons, the permit is not issued. Authorities claim that the permit is denied even

\footnotetext{
92 Letter from HaMoked to Major General Eitan Dangot, Coordinator of Government Activities in the Territories, 10 June 2010, http://www.hamoked.org.il/files/2010/112960.pdf (in Hebrew).

93 See footnote 44 above, Article 5(a).

94 AP 50482-07-10, Abreika et al. v. Commander of Gaza Area et al., decision, 5 August 2010.
} 
when the security concern does not apply to the woman herself, but rather to a member of her extended family, because the frequent passage of Israeli women between Gaza and Israel may render them vulnerable to exploitation by terrorist groups. When authorities announce that security clearance has not been given, the reasons are not disclosed. There is no possibility to appeal the decision other than by petitioning the HCJ. Even then, the security-related material is presented to the court in a classified manner, and the women cannot learn its contents. In several petitions that HaMoked filed with the $\mathrm{HCJ}$, the state agreed to allow passage between Gaza and Israel, under conditions that limited the frequency of visits but did not prevent them entirely, so as to enable the couple to have an adequate routine..$^{95}$ In the past, there have been cases in which the state objected to any agreement at all, preventing the couple from meeting altogether - a state of affairs that led, in some cases, to separation or divorce. ${ }^{96}$ In recent years, HaMoked has not encountered such cases.

\section{Pressuring Israeli citizen raised in Gaza not to return to Israel}

Sisters N. and M. are Israeli citizens - born to an Israeli mother and a Gazan father who have lived all their lives in the Gaza Strip. Even after they were eighteen, their permits to stay in Gaza were repeatedly renewed without any problem, and they had no idea that this was a deviation from the "split family procedure". The sisters continued studying at high-school and then at university in Gaza, renewing their permits while in Gaza or while in Israel, when visiting there. In October 2010, when $\mathrm{N}$. was 23 years old, she entered Israel to visit her family and, as usual, submitted a request to return home to Gaza. For five months, the "Israelis' Office" at the DCO repeatedly informed HaMoked that her request was being processed. On one occasion, HaMoked was notified that N. would be able to re-enter Gaza only on humanitarian grounds. During that long period, N. had to stay in Israel. At one point, she even found work in Israel, so as not to be a burden to her relatives.

In March 2011, about five months after filing the request to return to Gaza, the "Israeli's Office" informed HaMoked that "due to an error, your client was permitted to stay in Gaza after reaching the age of eighteen, but that does not

95 See, for example, HCJ 5535/11, A-Sana' v. OC Southern Command et al., ruling, 22 September 2011; HCJ 5122/12, Abu Samhan et al. v. OC Southern Command et al., notice on behalf of the Respondent, 8 August 2012.

96 See, for example, HCJ 6409/08, 'Azbeh et al. v. OC Southern Command et al. For more information, see HaMoked website: http://www.hamoked.org/Document.aspx?dID=606_update. 
entitle her in any way to leave Israel and enter Gaza at present..97 HaMoked petitioned the $\mathrm{HCJ}$, demanding that $\mathrm{N}$. be allowed to re-enter Gaza. In response, the state declared that it would not object to extending N.'s stay in Gaza under the "split family procedure" but stipulated that, should N. leave Gaza for Israel again, she would not be able to return. After some consideration, N. agreed to the condition, while HaMoked stressed that the state was imposing improper pressure on an Israeli citizen, forcing her to choose between living in Israel without her parents or living in Gaza with her family.

Meanwhile, her sister M., a university student in Gaza, made no attempt to renew her permit for fear that she, too, would be forced to leave Gaza, stop her studies and live away from her family. Eventually, both sisters chose to relocate to Israel, despite the forced separation from their parents, who remained in Gaza.

\section{Revocation of residency - East Jerusalem}

Residents of East Jerusalem married to residents of the Gaza Strip face additional obstacles. After occupying Gaza and the West Bank, Israeli law was applied to East Jerusalem and to thousands of hectares of land around it, and people living there were accorded permanent Israeli residency. Some twenty years later, the meaning of this form of residency became clear: The state's position, ratified by the $\mathrm{HCJ}$, is that this status "expires" when the person does not actually live in Jerusalem..$^{98}$ For that to occur, not meeting one of three conditions detailed in the regulations for entering Israel suffices: 1. Absence from Israel for at least seven years. 2. Receiving a permanent license to live in another country. 3. Naturalization in another country. ${ }^{99}$

In the first few years of the occupation, these regulations were rarely enforced. However, in December 1995, the Israeli Ministry of the Interior launched a new policy of revoking the permanent residency status of East Jerusalem residents who had not lived in the city for more than seven years - even if they had returned to renew their permits to leave Israel, and even

97 Letter to HaMoked from Command Sergeant Major 'Amer Nasraldeen, Commander of the "Israelis' Office" at the Gaza DCO, 17 March 2011.

98 HCJ 282/88, 'Awad v. Prime Minister and Minister of the Interior, IsrSC 42(2) 424 (1988).

99 Regulations on Entry into Israel, 5734-1974, Regulation 11 a. 
if they had lived in the West Bank or in Gaza. ${ }^{100}$ Following an HCJ petition filed by HaMoked and other human rights organizations, then-Minister of the Interior Natan Sharansky submitted an affidavit to the court in March 2000, stating that the new procedure would be terminated and that the ministry would revert to its former policy, under which residents maintaining a"proper affiliation" with Jerusalem would not have their status revoked. It was further stated that the ministry would reinstate residency status from whom it had been revoked after 1995, on condition that they spend at least two years in Jerusalem. Residents who had not been notified that their residency status had expired would be treated as though their residency had not expired..$^{101}$

Over the years, the Ministry of the Interior provided HaMoked and B'Tselem with data indicating that, from 1967 to 2012, Israel revoked the residency of more than 14,200 Palestinians in East Jerusalem. According to the data, the scope of the revocations varied, peaking at 4,577 in 2008.

East Jerusalem residents living in Gaza under the "split family procedure" do not lose their Israeli residency, as long as they regularly renew their permits. However, they are sometimes told at Erez Checkpoint that their ID cards are old and worn and must be renewed. When they go to the Ministry of the Interior to have new cards issued, the clerks refuse on the grounds that they do not actually live in Jerusalem. After considerable bureaucratic hassle, the ministry gives them a substitute identification document - instead of an ID card - that will allow them to re-enter Gaza.

M.B., a resident of East Jerusalem, went to the Ministry of the Interior on 24 July 2011 and asked to have her ID card renewed. The ministry clerks subjected her to immense pressure to register as a resident of Gaza, and one clerk even claimed that this was all they could do to help her. M.B. refused, one reason being that having a Palestinian ID card would render her a resident of another entity, which may serve as grounds to revoke her Israeli residency. A representative from HaMoked that was accompanying her was not allowed to intervene. Eventually, an identity document was issued M.B. that day, not a new ID card.

100 See HaMoked and B'Tselem, The Quiet Deportation Continues: Revocation of Residency and Denial of Social Rights of East Jerusalem Palestinians, September 1998, pp. 7-8.

101 HCJ 2227/98, HaMoked et al. v. Minister of the Interior et al., Additional Respondent's Affidavit, 15 March 2000 ("the Sharansky Affidavit): http://www.hamoked.org/items/3055_eng.pdf. 


\section{B. Visits by Israelis to the Gaza Strip}

\section{Procedure}

When the second intifada broke out, Israel raised the bar for issuing permits for Israelis to visit the Gaza Strip. In a ruling given in 2002, Chief Supreme Court Justice Aharon Barak explained that visiting Gaza does not come under the freedom of movement to which Israelis are legally entitled:

Entering a closed military zone is not leaving the country and is not included in the constitutional right to leave Israel. That applies to the matter of the Appellants' freedom of movement. Indeed, the territory under discussion has been declared a closed military zone. Therefore, the Appellants - or any other individual - no longer have the right to enter the said territory, as a fulfillment of their freedom of movement. ${ }^{102}$

At present, permits for Israelis to enter Gaza not under the "split family procedure" are issued only for humanitarian cases and in unusual circumstances: visiting a seriously-ill first-degree relative, attending a wedding or a funeral of a firstdegree relative, or accompanying a person who has been issued such a permit - spouses or minors under the age of eighteen. Entry is contingent on receiving security clearance. These criteria were formulated in August 2004, as part of the state's response to a petition filed by HaMoked. ${ }^{103}$

Until the second intifada began, Israel used to permit Israeli citizens and residents to enter Gaza during the Muslim major holidays ('Eid al-Fitr and 'Eid al-Adha) and during the Christian high holidays (Christmas and Easter). These visits were a rare opportunity to hold family gatherings. During the second intifada, Israel stopped this practice. In 2004, following petitions filed by HaMoked, the state undertook to enable holiday visits and even agreed that, should the visits not take place for any reason, an alternative date for holding them would be set. ${ }^{104}$

From 2005 to 2012, HaMoked filed seven HCJ petitions demanding that the state be ordered to fulfill the obligation it had undertaken and to enable the holiday

102 HCJ 9293/01, Barakeh et al. v. Minister of Defense et al., IsrSC 56(2) 509 [2002].

103 HCJ 10043/03, Abajian et al. v. Commander of the IDF Forces in the Gaza Strip, complementary response (no. 2) on behalf of the Respondent, 27 August 2004, parag. 22.

104 HCJ 10043/03, Abajian et al. v. Commander of the IDF Forces in the Gaza Strip; HCJ 1034/04, Qotina et al. v. Commander of IDF Forces in the Gaza Strip. 
visits. ${ }^{105}$ Following the first three petitions filed, the visits were indeed renewed. However, ever since Hamas took over control of the Gaza Strip in 2007, the state has objected to allowing such visits, and all HCJ petitions filed by HaMoked on the matter have been rejected or dismissed. In 2012, the HCJ refused once more to order the state to enable holiday visits. The justices noted: "We regret the prolonged separation between the Appellants and their relatives, but at this time, too, we see no possibility of helping them."106 Without these holiday visits, the families can almost never meet, except under exceptional humanitarian circumstances.

Even those Israelis who meet the criteria for visiting Gaza must face procedural obfuscation and incoherence. Varying responses to similar requests for humanitarian visits and arbitrary decisions concerning the severity of illness that constitutes humanitarian concern make it hard to predict how Israel will respond to a request to enter Gaza, even when the formal criteria are met. In addition, alleged lack of security clearance can be grounds for refusing a request. In addition, it is hard to predict how long it will take to receive an answer: HaMoked has handled many cases in which a long time elapsed from submission of the request until a response was received.

In its response to the $\mathrm{HCJ}$ regarding these problems, the state announced that "groundwork has been carried out to formulate principles for streamlining the work methods of the security bodies concerning the processing of requests to enter and exit the Gaza Strip... these are expected to shorten response time."107 The state did not mention explicit timeframes; however, since this notification in 2010, HaMoked has noticed a marked improvement in response time regarding permit requests.

According to COGAT data sent to B'Tselem, from 2009 to 2012, some 3,000 Israelis entered Gaza every year to visit relatives. Following is a breakdown of the data (the number of requests differs from the number of people entering as every family requests more than one permit): ${ }^{108}$

105 HCJ 552/05, HaMoked v. Commander of the IDF Forces in the Gaza Strip; HCJ 10135/05, HaMoked v. OC Southern Command; HCJ 8451/06, HaMoked v. OC Southern Command et al.; HCJ 2823/07, HaMoked v. OC Southern Command et al.; HCJ 8250/07, HaMoked v. OC Southern Command et al.; HCJ 7235/09, HaMoked v. OC Southern Command et al.; HCJ 5649/12, Hamdan et al. v. OC Southern Command et al. 106 HCJ 5649/12, decision, 16 August 2012.

107 HCJ 3757/09, Abaijan et al. v. OC Southern Command et al., updating notice on behalf of the Respondents, 22 February 2010.

108 Letter to B'Tselem from COGAT Spokesperson Major Guy Inbar, 10 July 2013, in response to B'Tselem's request for information under the Freedom of Information Act, 2 April 2013. 


\begin{tabular}{|l|l|l|l|l|}
\hline Year & $\begin{array}{c}\text { Requests } \\
\text { submitted }\end{array}$ & $\begin{array}{c}\text { Requests } \\
\text { granted }\end{array}$ & $\begin{array}{c}\text { Requests } \\
\text { rejected }\end{array}$ & $\begin{array}{c}\text { Number of } \\
\text { Israelis who } \\
\text { actually } \\
\text { entered } \\
\text { Gaza Strip }\end{array}$ \\
\hline 2009 & No data & No data & No data & 3,071 \\
\hline $2010^{109}$ & 1,568 & 949 & 597 & 3,283 \\
\hline 2011 & 1,469 & 972 & 497 & 3,063 \\
\hline 2012 & 1,258 & 785 & 473 & 3,756 \\
\hline
\end{tabular}

\section{Illustrative Cases}

\section{Prevention of entry into Gaza even in humanitarian cases}

\section{Intermittent prevention on security grounds}

A. was born in the Gaza Strip, married a resident of East Jerusalem, and was accorded permanent residency in Israel in February 1995 under the "family unification procedure". He was arrested in May 1995 and released without charges. Two months later, A. entered Gaza to visit his family. Over the course of the following five years, although HaMoked repeatedly applied on his behalf, he was not allowed to enter Gaza, on security grounds. For five years after that, A. made no attempt to visit Gaza. In 2005, he applied again for a permit and, on 12 April 2005, was issued a permit to enter Gaza with his children. In August of that year, he again entered Gaza, after a permit he had been given for June had not been used due to an escalation in violence in the area.

In October 2005, A.'s mother was diagnosed with breast cancer, compounding existing medical problems. A., a registered nurse, wanted to accompany his mother to medical treatments and look after her. He also wanted to bring her the necessary medication from Jerusalem that could not be obtained in the

109 In 2010, the total number of requests submitted was higher than the total number of requests that received responses (either approved or denied), as 22 requests were sent back for applicants to complete additional data or documents. 
Gaza Strip. Twelve days after filing a request, he was issued a permit. Over the next year, he entered Gaza regularly, with permits issued several days to two weeks from submission of his request. In October 2006, A. requested to enter Gaza with his fifteen-year-old son, but the permit was only approved in midFebruary 2006, by which time the boy was sixteen. On 1 March 2007, A. and his son arrived at Erez Checkpoint, where the son was forbidden to enter on the grounds that his age warranted security clearance. A. and his son entered Gaza only on 10 April 2007. A request that A. submitted on 5 June 2007, shortly before Hamas took control of the Gaza Strip, was approved only more than two months later, on 21 August 2007.

On 30 September 2007, A. submitted another request. However, on 13 November 2007 , he received a surprising notice that it was denied for security reasons. ${ }^{110}$ HaMoked petitioned the $\mathrm{HCJ}^{111}$ and, three days later, received a phone call from the State Attorney's Office that the request had been granted. A.'s subsequent requests were also granted.

On 30 October 2008, HaMoked filed another request on A.'s behalf, to coordinate his entry into Gaza. Months elapsed without a permit being issued, and HaMoked again petitioned the HCJ, on 26 February $2009 .{ }^{12}$ In response, the state claimed that A.'s entry into Gaza had been denied for his own safety ${ }^{113}$ - despite the fact that $A$. was born and bred in Gaza, had family there, and had visited there on many previous occasions. On 6 April 2009, he was issued a permit to enter Gaza, even before the court proceedings had ended. From then until August 2010, A. repeatedly received permits to enter Gaza, with response times to his requests ranging from a week to a month and a half.

On 1 September 2010, in response to a HaMoked query, the organization was notified that A.'s request for a permit had been denied, and that he would be able to coordinate entry into Gaza only three months from the date of his last entry. HaMoked's request for clarification of the legal grounds for the restriction went unanswered. From that point on, A. requested permits to enter Gaza only once every three months. Still, responses were sometimes received only seven weeks after the request was filed, and then only when HaMoked threatened to petition the court on the matter. 


\section{Delays in issuing permits to visit terminally ill patients}

$\mathrm{H}$. is an Israeli whose eighty-year-old mother lives in the Gaza Strip. In February 2010, after her mother's condition deteriorated, including heart problems and other complications, $\mathrm{H}$. filed a request to visit her. The request was approved only two months later. ${ }^{114}$ In December 2012, her mother was hospitalized in critical condition, but was released after the hospital decided that no more could be done for her. On 3 December 2012, HaMoked applied to the "Israelis' Office" requesting that $\mathrm{H}$. be permitted to visit her dying mother. ${ }^{115}$ The permit was only issued on 9 December 2012 at midday, shortly before Erez Checkpoint closed. H.'s mother died the next day, before $\mathrm{H}$. had a chance to see her. $\mathrm{H}$. entered Gaza to attend her mother's funeral.

A., a resident of Beersheba, Israel, submitted a request on 18 April 2012 for a permit to visit her sister, a resident of Gaza, who was in hospital with a severe infection. ${ }^{16}$ As she received no response for over two months, HaMoked petitioned the $\mathrm{HCJ} .{ }^{117}$ The very next day, A. was issued a three-day permit to visit her sister. ${ }^{118}$

114 Letter from HaMoked to the "Israelis' Office" at the Gaza DCO, 23 February 2010; the permit was received on 18 April 2010.

115 Letter from HaMoked to the "Israelis' Office" at the Gaza DCO, 3 December 2012.

116 Letter from HaMoked to the "Israelis' Office" at the Gaza DCO, 18 April 2012.

117 HCJ 4985/12, A-Sana' et al. v. OC Southern Command, 26 June 2012.

118 Letter to HaMoked from the "Israelis' Office" at the Gaza DCO, 27 June 2012. 


\section{Harm to women caused by Israel's policy}

In traditional Palestinian society, women are expected to leave their home after marriage and move into their husband's home, or into a house near his. Some marriages, at least, are arranged by the extended family, and women do not have sole control over who they will marry, nor are they necessarily acquainted with the intended bridegroom or his family.

Israel's policy, as detailed in this report, is especially detrimental to women and to their daily lives. Leaving one's family home and familiar surroundings can be difficult even under the best of circumstances; ${ }^{119}$ these women are under much more duress, as the restrictions on their freedom of movement effectively sever them from their families of origin. They raise their children without the support of their extended families and must rely on their husband's relatives, with whom they were perviously unacquainted. They have no one to support them in emotionally stressful situations - not even in the extreme circumstance of domestic violence. If a couple divorces, the wife is traditionally left with nothing, not even her children. Divorced women who have the option of returning to their families of origin are forced to live separately from their children. Even if a man is prepared to allow his ex-wife to see their children, the movement restrictions described in this report make it extremely difficult. Israel does not enable any passage between Gaza and the West Bank, while the "split family procedure" that governs passage between Gaza and Israel applies to children of such couples only when they are underage, and at any rate does not allow for regular contact between parents and children living apart.

The fact that these women are cut off from their familiar surroundings and from their support and safety networks enhances their inherently weak position

119 See, for example, L. Abu-Tabeeh, "Immigrants among Their People: How Palestinian Women in Israel Experience Immigration after Marriage", M.A. thesis, Department of Gender Studies, Bar Ilan University, 2008 (in Hebrew). 
within a patriarchal structure. For example, a woman who lives in the West Bank but whose listed address is in Gaza will refrain from leaving her house or her town for fear of being arrested, expelled from the West Bank, and severed from her children and her new family. As a result, she becomes totally dependent on her husband and his family.

\section{A. Marriage and moving into the husband's home}

When an Israeli woman marries a resident of the Gaza Strip, procedure allows her entire nuclear family to enter Gaza for the wedding. However, if the wedding is between a West Bank resident and a Gaza resident, Israel places obstacles in their way from the outset - regarding both the bride's participation in her own wedding and the attendance of her family.

For example, 'A., a resident of Gaza, wished to marry a resident of Tul Karm, the West Bank. 'A., her parents and her siblings requested permits to travel to the wedding and stay in the West Bank for the duration of the various ceremonies. HaMoked applied to the Civil Administration on their behalf and was informed that, as the family members "do not meet criteria", their request was denied. It was only after the family petitioned the $\mathrm{HCJ}$ that the state agreed to allow them to travel to the West Bank and stay there for two weeks. As for the bride - she was allowed to stay in the West Bank for two months, during which she would be able to take care of updating her listed address. ${ }^{120}$

Accordingly, after the wedding, 'A. applied for an address change, but the application was rejected, and HaMoked re-petitioned the HCJ. ${ }^{121}$ Further to this petition and others, the state formulated the "relocation procedure" detailed above, which does not enable a resident of Gaza who marries a resident of the West Bank to relocate to the West Bank. ${ }^{122}$ 'A.'s address was finally updated in January 2012, as part of Israel's diplomatic gesture of goodwill towards the Palestinian Authority.

Asmaa Zaghlul was born in the Gaza Strip and met her future husband in Jordan. When she was 22, the two wed. Zaghlul, who has lived in Nablus since her marriage, told B'Tselem how lonely she felt on her wedding day: 


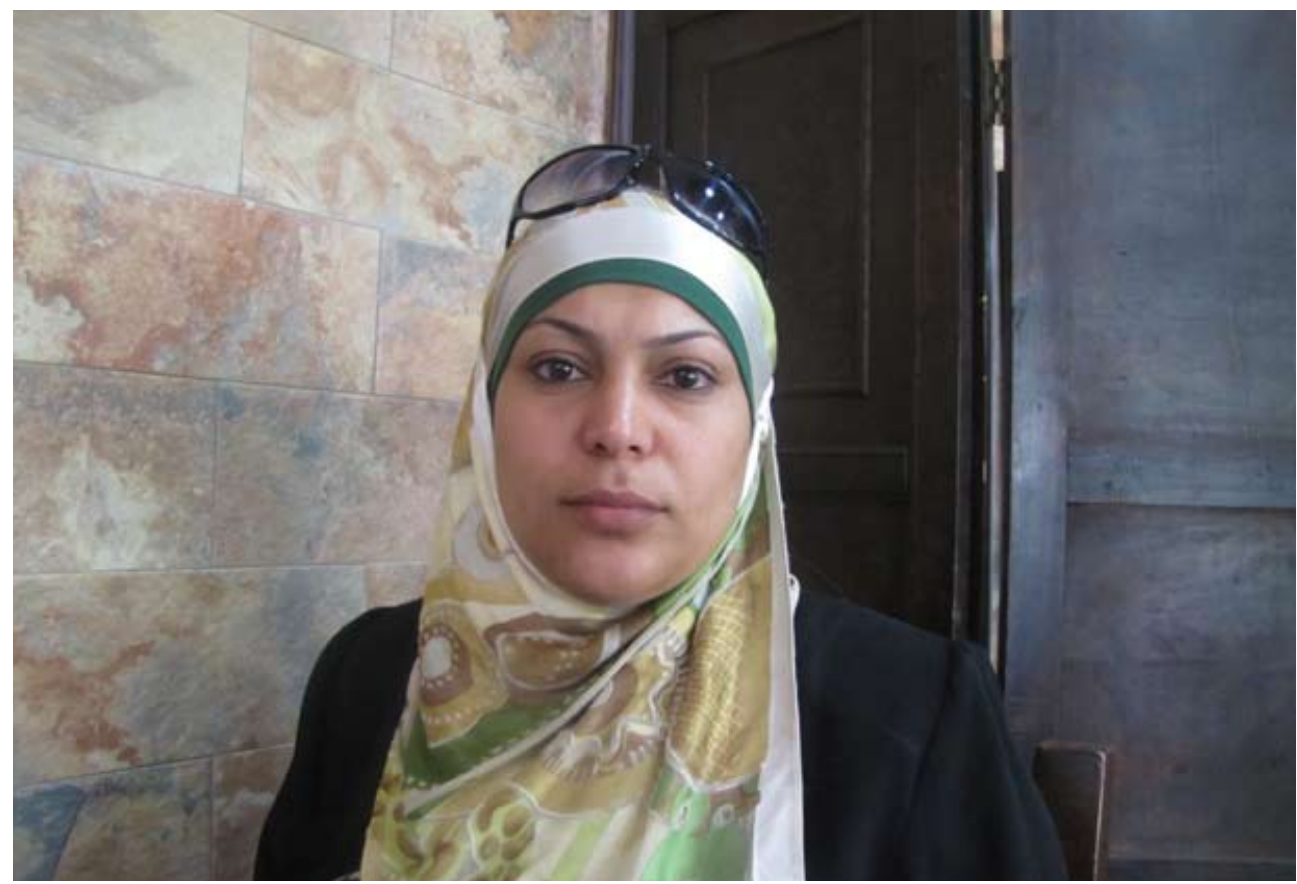

Asmaa Zaghlul. Photo by Salma a-Deb'i.

I traveled to Nablus with my mother and father with an entry permit for only three days. My eight brothers and sisters didn't get permits. We got to Nablus, and the wedding was the next day. Everyone at the wedding was happy but me. I couldn't stop crying and I felt so sad about saying goodbye to my family, because l'd never imagined that on my wedding day l'd be without my brothers and sisters and relatives and friends. I felt lonely and sad. ${ }^{123}$

In another case, Israel's refusal to update the address of a Gaza resident caused a marriage to break up. In January 2007, H.A. married a West Bank resident, in Gaza. A month later, her husband had to go back to the West Bank because his father had fallen ill. H.A.'s situation was a delicate one: it was her second marriage, and her three daughters had remained in her ex-husband's custody, while she was given no chance to even meet them. Her ex-husband had tarnished her reputation to a degree that affected her sisters' chances of marriage and harmed her family. Therefore, H.A. very much wanted to leave her parents' home and felt that her second marriage was a true opportunity to start a new and happy life. 
For two and a half years, the couple tried to arrange for H.A. to relocate to the West Bank, but Israel refused to allow it. ${ }^{124}$ Israel even refused H.A.'s request to travel to the West Bank to attend a wedding party that the couple had planned to have with her husband's family, and did not relent even after a petition was filed before the HCJ. ${ }^{125}$ Once the couple decided to separate, the petition was cancelled. ${ }^{126}$

\section{B. Married life}

As it is so hard to obtain permits to visit Gaza, many Gazan women who moved to the West Bank after marrying a local resident do not even attempt to return to visit their families. Women whose addresses Israel refuses to update are afraid to travel in the West Bank for fear that they will be expelled and sent back to Gaza. Asmaa Zaghlul told B'Tselem that, in the nine years during which her listed address was still in Gaza, she was unable to visit her family there: had she gone to Gaza, she would not have been able to return to her husband and children in the West Bank.

Over the years, Zaghlul filed several requests to have her address updated, but all were denied. Her address was only updated in 2011. In August 2012, she visited Gaza with her children, taking the arduous route through Jordan and Egypt. Only then did she finally get to see her family again, and her children first meet their mother's family. Zaghlul told B'Tselem how being reunited with her family of origin highlighted the daily hardship and emotional difficulty she undergoes living away from her family, making her regret the very choice to marry a resident of the West Bank:

What made me sadder was that, while I was in Gaza, I noticed how important my mother and father's presence is in the lives of my brothers and sisters. They help them with every aspect of their lives, and especially with the children. I saw how attached my nieces and nephews are to my parents. If one of the kids is sick, my parents help care for him and for the other kids, and if one of my sisters wants to go shopping or to visit a friend, she leaves her kids with my dad. These things may sound trivial, but they're very important. I work at a family conflict resolution center in Nablus. I have three children. The eldest is eight, and they need constant care and attention. If I could turn back the

124 Two letters sent from Gaza DCO on the same day, 4 March 2008, cited two different reasons for the refusal: security grounds and not meeting the required criteria.

$125 \mathrm{HCJ} 2430 / 08$, Abu Ghali et al. v. Military Commander in the West Bank.

126 Ibid., decision, 12 September 2012. 


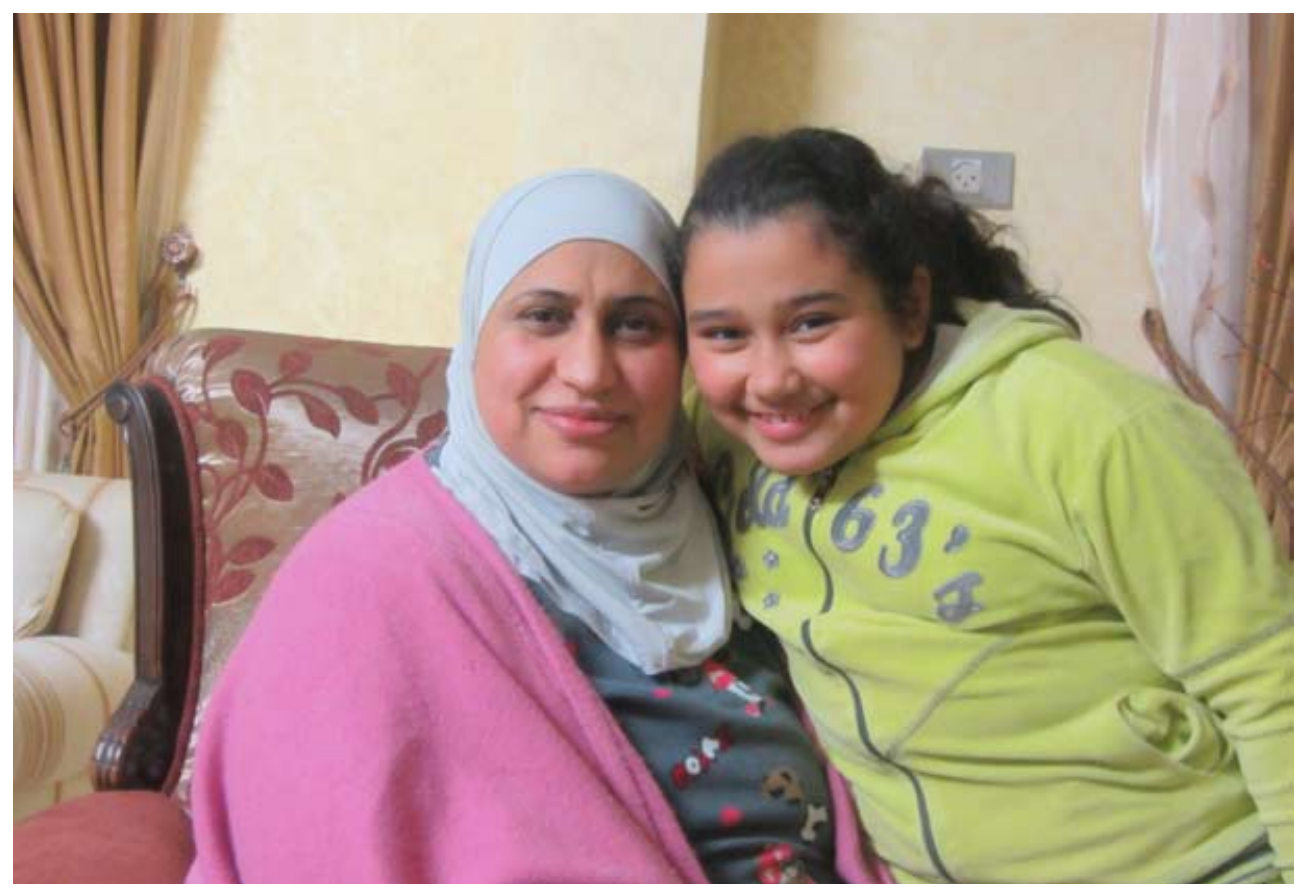

'Abir Sharaf and her daughter Jana. Photo by Salma a-Deb'i.

years, I wouldn't marry someone who lives outside Gaza. I didn't know how much l'd suffer.

We, Gazan women who live in the West Bank, away from our families, without being able to visit them, are in a very difficult position. It's the epitome of injustice and violation of basic human rights, because every human being has the right to see their family and loved ones. ${ }^{127}$

The long, expensive journey from the West Bank to the Gaza Strip via Jordan and Egypt, often in the company of young children, makes such travel very difficult. 'Abir Sharaf from Nablus described her feelings:

Sometimes, I worry that Israel won't ever allow me to visit my parents, and that I'll always have to travel through other countries to get to my parents' house, where I was born and raised. I think it's an injustice. I'm always sad and feel like I'm in mourning, especially when I see other married women going to their parents' homes, and when their parents visit them on holidays and special occasions and during Ramadan. I just want to spend one day with my mother, on Mothers' Day. I want to kiss her hand and hug 
her. I want to be the first one to greet her on that day. I want to be able to go shopping with my sisters, like all sisters do. I want to go over to my brothers and sisters and have fun with them together with my boys. I want my kids to have fun with their aunts and uncles and cousins. ${ }^{128}$

Many of the women that B'Tselem interviewed stated that they had not understood the implications of being separated from their families of origin before they got married. 'Abir Sharaf related how she became depressed as a result:

In 2010, my brother got married and I really wanted to go to his wedding. I packed my suitcase, after they told me at the Palestinian DCO that they would try to get me a permit to enter Gaza, because I cried a lot and begged them to help me. But, in the end, they didn't manage to get it. I felt very bad and the doctor diagnosed me with depression. I really wanted to go to my home in Gaza, to where my parents and brothers and sisters live. I so much wanted to be with them and share their joys and sorrows. I wanted to share their grief when my uncle died in 2011, and on a lot of other occasions. My grandmother passed away, too, in 2007 . She was the one who raised me. ${ }^{129}$

\section{End of marriage}

\section{Sent away from home, returning out of devotion to the children}

In traditional Palestinian society, the status of divorcees is a sensitive one, and a divorced woman is expected to move back to her father's home. The children remain with the father and, in some cases, the mother is not even allowed to see them. When the woman's family is in Gaza and the children are in the West Bank, or vice versa, the situation is even worse. M.I., who was born in Qalqiliya, married a resident of Gaza in 2005 and moved to Gaza to live with him in 2009. In September 2010, the couple had a falling out. The husband subsequently made M.I. and their three children leave the house, and they moved in with strangers who agreed to house them temporarily. At the end of October 2010, M.l's husband and his family took away the three children, later giving back the baby, for whom they had difficulty caring. In November, M.l. was made to leave the temporary accommodation, and a community mental health center 
tried to assist her. ${ }^{130}$ There are no women's shelters in Gaza for women in M.I.'s situation. It was only after HaMoked repeatedly applied on her behalf that M.I. was allowed to travel to the West Bank on 2 December 2010, and she relocated there with her infant child. ${ }^{131}$

In January 2012, M.I. again contacted HaMoked. She asked for help with moving back to Gaza, as the children she had left there needed her very much. ${ }^{132}$ The Civil Administration stated that M.I. had to declare whether she intended to merely visit Gaza or settle there. ${ }^{133}$ For fear that she would be forced to sign a document promising that she would not return to the West Bank, M.I. had to enter the Gaza Strip via Rafah Crossing.

\section{Child custody battle waged between West Bank and Gaza}

Unlike divorce, in which the children remain in the father's custody, widowed women usually receive custody of their children.

H.M., a resident of Qalqiliya, the West Bank, moved to the Gaza Strip to live with her husband. In November 2010, with H.M. three-months-pregnant, the couple divorced. The ex-husband immediately remarried, and his new wife raised H.M.'s three children. The ex-husband's family allowed H.M. to meet only with her youngest son, once a week. Two months after the divorce, in January 2011, H.M. applied to the Committee for Civilian Affairs and asked to return to her parents' home in the West Bank; she received no response. HaMoked tried to obtain a permit for her to enter the West Bank in May, ${ }^{134}$ before her due date, and even petitioned the $\mathrm{HCJ}$ on the matter, ${ }^{135}$ but the Israeli authorities did not respond. H.M. gave birth in the Gaza Strip on 2 June 2011, and was only later permitted to go to the West Bank with her baby.

In July 2011, H.M.'s ex-husband passed away, and she filed for a permit to enter Gaza to take her children. ${ }^{136}$ After HaMoked petitioned the HCJ, ${ }^{137}$ H.M. was allowed to enter Gaza for a week, and her visit was extended at her request.

130 Report by Gaza Community Mental Health Programme, 28 November 2010.

131 Letter to HaMoked from the Humanitarian Hotline at the Gaza DCO, 2 December 2010.

132 Letter from HaMoked to Second Lieut. Bar Akuka, Public Complaints Officer at the Civil

Administration.

133 Phone call to HaMoked from Second Lieut. Bar Akuka, Public Complaints Officer at the Civil

Administration, 23 February 2012.

134 Letter from HaMoked to the Humanitarian Hotline at the Gaza DCO, 24 May 2011.

135 HCJ 4213/11, Mghari et al. v. Military Commander in the West Bank.

136 Letter from HaMoked to the Humanitarian Hotline at the Gaza DCO, 21 August 2011.

137 HCJ 6285/11, Mghari et al. v. Military Commander in the West Bank. 
Ultimately, the ex-husband's family kept her from taking her children, and she returned to the West Bank with the baby only, on 9 October 2011. ${ }^{138}$

On 9 August 2012, H.M. filed a request with the DCO in Qalqiliya to enter Gaza to visit her children. As she received no response, HaMoked applied on her behalf three weeks later, requesting that she be permitted to enter the Gaza Strip and remain there with her children until the family conflict was resolved and she could bring them to Qalqiliya. ${ }^{139} \mathrm{HaMoked}$ received no response and petitioned the HCJ. ${ }^{140}$ After repeated discussions between HaMoked and the State Attorney's Office, H.M. entered Gaza on 10 February 2013, leaving the baby with her family in the West Bank. She made the trip after prolonged negotiations with her ex-husband's family about taking the children to the West Bank with her. When H.M. entered Gaza, the family did agree for her to take the children with her. The next day, H.M. submitted a request to be allowed to do so, so that she could leave as quickly as possible, before her ex-husband's relatives could change their minds. At the same time, HaMoked applied to the authorities on her behalf. Despite these efforts, H.M. only managed to move from Gaza to the West Bank with her children almost a month later, on 5 March 2013. ${ }^{141}$

\footnotetext{
138 Ibid., decision, 11 October 2011.

139 Letter from HaMoked to Second Lieut. Bar Akuka, Public Complaints Officer at the Civil Administration, 28 August 2012.

140 HCJ 7711/12, Mghari et al. v. Military Commander in the West Bank.

141 HaMoked was notified that approval had been granted in a letter from the Humanitarian Hotline at the Gaza DCO, dated 4 March 2013.
} 


\section{Israel's policy considered in view of international law}

Israel's policy concerning the family life of couples where one spouse is a resident of the Gaza Strip and the other a resident of the West Bank or Israel constitutes a severe violation of their rights, as will be explained below.

The question whether the Gaza Strip is still legally considered occupied territory has no bearing on Israel's obligations on the issues examined in this report. As Israel controls Gaza's borders, including exclusive control of all crossing points between Gaza and the West Bank, it bears obligations towards the civilian population in Gaza. Israel's duty towards the residents of Gaza is amplified by the fact that the latter have been dependent on Israel since 1967..$^{142}$ Moreover, the subject matter of this report covers more than the Gaza Strip: Israel is still the occupying power in the West Bank and is, therefore, legally bound to protect the rights of residents there, not to mention its obvious duty to safeguard its own citizens and residents.

\section{A. The right to family life}

The right to family life is enshrined in international law, which determines that arbitrary interference with a person's family life is unacceptable. The International Covenant on Civil and Political Rights states that every person has the right to establish a family, and that the family is "the natural and fundamental group unit of society and is entitled to protection by society and the State."143 Under the International Covenant on Economic, Social and Cultural Rights, states are bound to protect and assist the family unit, especially when the family is responsible for the care and education of children. ${ }^{144}$ The official interpretation of 
this obligation includes the obligation to enable partners to live together - and states are charged with facilitating the unification of families, including when this requires collaboration with other states. ${ }^{145}$ The Covenant also emphasizes that cultural differences relating to the scope and definition of the family unit must be taken into account, as must be the extent of protection necessary for different degrees of family kinship. ${ }^{146}$ Israel is a signatory to these covenants and is bound by them.

Under international humanitarian law (IHL), states must protect the right to family life of residents of occupied areas. ${ }^{147}$ According to the official Red Cross commentary, the purpose of that article is to preserve marriage and the family unit as a whole, consisting of parents and children, which is "the natural and fundamental unit of society". ${ }^{148}$

Like most human rights, the right to marry and establish a family is not absolute. States are allowed to restrict fulfillment of that right, albeit under specific circumstances only. According to the International Covenant on Civil and Political Rights, for example, the state's interference in a person's family life must not be arbitrary. ${ }^{149}$ As a rule, the Covenant allows signatory states to derogate from their obligations only "[i]n time of public emergency which threatens the life of the nation", and then only "to the extent strictly required by the exigencies of the situation".150

The Convention on the Rights of the Child is emphatic regarding children's rights to be raised in their nuclear family. ${ }^{151}$ Under Article 9, "State Parties shall ensure that a child shall not be separated from his or her parents against their will, except when competent authorities subject to judicial review determine, in accordance with applicable law and procedures, that such separation is necessary for the best interests of the child." Under Article 10, children have the right to maintain contact with both parents on a regular basis, even when

145 See Office of the High Commissioner for Human Rights, General Comment No. 19: Protection of the family, the right to marriage and equality of the spouses (Art. 23): 27/07/1990, 5: http://www.unhchr.ch/tbs/doc. nsf/0/6f97648603f69bcdc12563ed004c3881?Opendocument.

146 Ibid., Article 2.

147 The Fourth Geneva Convention relative to the Protection of Civilian Persons in Time of War, Article 27: http://www.cicr.org/applic/ihl/ihl.nsf/Treaty.xsp?documentld=AE2D398352C5B028C12563CD002D6B5C\&ac tion=openDocument.

148 Jean S. Pictet (ed.), Commentary: IV Geneva Convention Relative to the Protection of Civilian Persons in Time of War, Geneva: International Committee of the Red Cross, 1958, Article 27, Para 1 (c), p. 202.

149 The International Covenant on Civil and Political Rights, Article 17.

150 Ibid., Article 4.

151 The Convention on the Rights of the Child: http://www2.ohchr.org/english/law/crc.htm. 
fulfillment of that right requires travel between countries. The Article further states:

Towards that end [...], States Parties shall respect the right of the child and his or her parents to leave any country, including their own, and to enter their own country. The right to leave any country shall be subject only to such restrictions as are prescribed by law and which are necessary to protect the national security, public order (ordre public), public health or morals or the rights and freedoms of others and are consistent with the other rights recognized in the present Convention.

IHL also recognizes the authority of states to derogate from some of their obligations, as long as military needs necessitate such action. For instance, the Fourth Geneva Convention, states with regard to the obligation to respect the family rights of protected persons in occupied territory that "the Parties to the conflict may take such measures of control and security in regard to protected persons as may be necessary as a result of the war". ${ }^{152}$ The official commentary of the Red Cross concerning this article notes that, despite the relative freedom accorded states regarding the restrictions they are permitted to impose, it is essential that the restrictive measures used do not violate the basic rights of the persons involved. ${ }^{153}$

\section{B. The right to freedom of movement}

The International Covenant on Civil and Political Rights states that "[e]veryone lawfully within the territory of a State shall, within that territory, have the right to liberty of movement and freedom to choose his residence." As with other human rights, states may limit this right: "The above-mentioned rights shall not be subject to any restrictions except those which are provided by law, are necessary to protect national security, public order (ordre public), public health or morals or the rights and freedoms of others, and are consistent with the other rights recognized in the present Covenant." ${ }^{\prime 154}$

152 The Fourth Geneva Convention relative to the Protection of Civilian Persons in Time of War, Article 27. http://www.cicr.org/applic/ihl/ihl.nsf/Treaty.xsp?documentld=AE2D398352C5B028C12563CD002D6B5C\&act ion=openDocument, see footnote 147 above.

153 Pictet, p. 207, see footnote 148 above.

154 The International Covenant on Civil and Political Rights, Article 12. 
The Oslo Accords classified the West Bank and the Gaza Strip as a single territorial unit. Consequently, residents have the right to move freely between these areas. The view defining the two areas as a single territorial unit was upheld in a 2002 Supreme Court ruling, which stated that forced transfer of West Bank residents to the Gaza Strip was not expulsion but rather relocation in the same occupied area, as defined in Article 78 of the Fourth Geneva Convention. ${ }^{155}$ Israel has since changed its position, and now claims that the West Bank and the Gaza Strip are "two separate and different areas". ${ }^{156}$ However, no official change has been made based on an agreement between the parties, and Israel's unilateral change of approach cannot change residents' basic rights.

Persons wishing to travel between the West Bank and the Gaza Strip must enter Israel: not in order to stay, but simply because the only reliable way to cross between these two parts of a single territorial unit passes through Israeli territory. While West Bank residents can reach Gaza via Jordan and Egypt, doing so entails a lengthy and expensive journey. Gazan residents do not have the equivalent option, as Israel and Jordan prohibit them from entering the West Bank via Allenby Bridge.

In this context, Israel must respect the 'right of transfer', which differs substantively from the right to enter the country. The right of transfer between two parts of the same country is not enshrined in international conventions. However, as regards the Gaza Strip, it is considered a customary right derived from historical agreements between states, mostly concerning access to the sea and to enclaves. The right of transfer means that, as long as passing through a country poses no harm to it, the transfer must be permitted, even if there are alternatives to doing so. Conditions may apply to the transfer in order to protect the legitimate interest of the country through which passage takes place, such as a prohibition on transferring weapons or dangerous substances. ${ }^{157}$ 


\section{Conclusions}

"Indeed, the Appellants' relatives are only a short drive away from here. You could almost reach out and touch them. But that short drive seems as long as a journey to the ends of the earth." ${ }^{158}$ This is how the High Court justices described the situation in August 2012, when they rejected a petition by HaMoked concerning Israeli citizens and residents visiting relatives in the Gaza Strip.

Any two points in the West Bank and the Gaza Strip are no more than a few hours' drive away, but Israel's almost blanket prohibition on travel between the two areas, or between Gaza and Israel, has severed them almost entirely. This policy has made daily life unbearable for families split between the two areas. Tens of thousands of people are forced to navigate this impossible reality, having the most intimate aspects of their lives subjected to state bureaucracy, through a series of procedures that set almost unattainable criteria. For these people, the simplest matters - starting a family, living together with one's spouse and children, and keeping in regular contact with the families of origin of both partners - can no longer be taken for granted.

Israel has adopted the view that the right to family life does not include a couple's right to choose where to live and that the state holds the power to make that decision. Only if the couple chooses to live together in the Gaza Strip will the state respect their choice. Israel argues that this view is based on the state's exclusive authority to determine who enters its territory, and on security concerns. It is difficult to accept these arguments:

First, even if Israel, like any sovereign country, may determine who enters its territory, its discretion in doing so is not unlimited. In cases concerning individuals wishing to realize their right to family life, the state must ensure that limitation of the right is proportionate and not arbitrary. In contrast, Israel a priori bars any possibility of fulfilling that right within its territory. Furthermore, Israel makes no distinction between requests to enter its territory in order to live there and requests to enter for transit only; it even goes so far as to prohibit travel from Gaza to the West Bank through Jordan. In doing so, Israel violates the 
right to family life both of its own citizens and residents, and of West Bank and Gaza residents.

Second, although Israel is within its rights to base criteria for entering its territory and passing through it on security considerations, such considerations must be applied individually. In practice, however, Israel uses a collective security argument, claiming that the Gaza Strip is a "hostile entity", which allegedly justifies placing absolute prohibitions on all its residents. Even if the policy described in this report was originally formulated based on security concerns, Israel clearly did not weigh these concerns against the affected families' rights to family life and to freedom of movement, explicitly favoring its own interests.

In addition, Israel strangely ignores its own arguments when it comes to a West Bank resident wishing to relocate permanently to Gaza. Israel so easily allows passage in such cases that one cannot help but wonder whether its declared considerations mask illegitimate demographic concerns. When the violation of such fundamental rights is not individually justified in each case, the overall policy constitutes a breach of Israel's obligations under international law.

For every case of the type described above that HaMoked handled, there are many others: People whose requests for permits were denied and did not apply to HaMoked or other organizations for assistance, or people who made no attempt to file such a request in the first place, knowing that the chance of a permit being issued was virtually non-existent. The deterring effect of this policy has created a reality in which it is impossible to evaluate the extent of the problem and the number of people denied the opportunity to visit their families.

B'Tselem and HaMoked call upon Israel to respect the rights of all Palestinian residents to family life and freedom of movement. Israel must enable free passage, subject to individual security inspections, between the Gaza Strip and the West Bank, and must allow couples where one partner is a resident of Gaza to choose where they wish to live. Israel must also enable Gaza residents married to Israeli citizens and residents to live in Israel with their spouses. In addition, Israel must enable residents of Gaza to maintain regular family ties with their relatives in Israel, in East Jerusalem, and in the rest of the West Bank. 


\title{
8. Appendix - Response by the Ministry of Justice
}

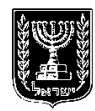 \\ State of Israel \\ Ministry of Justice \\ The Office of the Deputy Attorney General (International Law)
}

Date: $2^{\text {nd }}$ Tevet, 5774

$5^{\text {th }}$ December, 2013

Number: 1077

To:

Mrs. Naama Baumgarten-Sharon

"B'Tselem" Organization

8 HaTa'asiya Street, Talpiot

Jerusalem

Greetings,

\section{Re: Response to the Draft Report of the Organizations "B'Tselem" and "The}

\section{Center for the Defense of the Individual" -"Beyond the Dark Mountains"}

We received your enquiry regarding the abovementioned report and hereinafter is the response of the relevant authorities:

Firstly, it should be clarified that the facts presented in the report are not completely accurate, whilst ignoring the situation on the ground and are in part tendentious.

Secondly, our general response to the points raised in the report is as follows:

1. As is well known, foreigners have no vested right to enter the territory of the State of Israel, similarly to any other state in the world. This fact is even more pertinent when discussing entry to Israel from the Gaza Strip, a hostile territory controlled by a murderous terrorist organization that routinely operates against a civilian population and whose self-declared goal is the annihilation 
The Office of the Deputy Attorney General (International Law)

of the State of Israel. Given this state of affairs, and in light of the politicalsecurity situation, the State of Israel's policy is that, as a rule, residents of the Gaza Strip should be allowed to enter Israel (including for the purpose of crossing into the West Bank for humanitarian purposes only. Note that in 2005, Israel implemented and completed the disengagement plan, effectively ending Israeli rule over the Gaza Strip (in this regard please see H.C.J. 9132/07

Jaber Al-Bassiouni Ahmed et. al. v. The Prime Minister et. al. (30.1.08)).

$\therefore$ When dealing with residents of an enemy territory, and when terrorist organizations are seeking to shift their activities from the Gaza Strip to the West Bank, there can be no doubt that permitting the passage between the Gaza Strip and the West Bank would entail a substantial security risk. The Supreme Court addressed this security risk within the framework of denying a petition which sought to attack the relevant authorities' policy regarding requests to relocate from the Gaza Strip to the West Bank, and stated, inter alia, as follows:

"The logic behind this conception is clear - given the difficult security situation in which we live, and at a time when terrorist organizations in the Gaza Strip and in Judea and Samaria Area continue in their vigorous efforts to harm the State of Israel and its residents, there is a serious concern of permitting free travel between the two areas, due to the potential use of this platform to foster contacts between the terrorist groups in the various areas - military training, recruitment, transfer of information, orders, etc. This reality obligated that the State of Israel must retain its discretion when it comes to permitting the transfer from one area to another, a temporary or permanently [...]. With the demise of the military administration in the Gaza Strip in 2005, following the disengagement plan, and moreover - with the Hamas organization's takeover of the Gaza Strip in 2007, the concern for exploitation of the crossing between the areas to pursue a terrorist agenda has tremendously increased, especially in the absence of effective Israeli control in the Strip [...]. In the reality which has been created, especially since the completion of the disengagement process and the Hamas organization's takeover of the Strip, and in the light of the fact 


\section{The Office of the Deputy Attorney General (International Law)}

that the Gaza Strip is a separate territory, defined by a border fence, terrorist groups are finding it difficult to send their operatives into Israel. Nevertheless, an extensive terrorist infrastructure which strives to spread its human operatives into Israel and the West Bank exists in the Gaza Strip. According to estimates of security officials, the Gaza Strip has become a center of knowledge in the field of terrorism, and a storage for large quantities of advanced weapons and the development of military capabilities and the terrorist organizations wish to shift their war against Israel to the West Bank, through, inter alia, the transfer of knowledge, military capabilities and explosives experts. Therefore, recruitment of Gaza residents residing in the West Bank or who wish to move there, has become a common phenomenon, which has the potential to promote the goals of the terrorist organizations. Security officials stress that there is a grave threat of explosives experts, who are capable of preparing deadly explosive devices and high-trajectory weapons, infiltrating the West Bank [...]. This court has been called upon a number of times to assess the restrictive policy of the respondents but has not seen fit to interfere in it [...]" H.C.J. 2088/10

The Center for the Defense of the Individual et. al. v. Military Commander of the West Bank et. al. (24.5.12)).

3. Despite the aforementioned security situation, as a matter of policy and notwithstanding the absence of any legal obligation to do so, the State of Israel has decided to allow the entrance into Israel of Gaza Strip residents in exceptional humanitarian cases. Thus for example, Israel allows Gaza Strip residents to enter the country in order to receive urgent medical treatment, attend weddings of first degree relatives, etc. In addition, the State of Israel allows the movement of Gaza merchants and workers of international organizations, in order to enable the economic activity and the activities of international organizations operating in the Gaza Strip. Israel also allows its own citizens to enter Gaza, as a matter of policy, in humanitarian or "divided families" cases. Pursuant to this policy, and despite the fact that this is a hostile territory controlled by a terrorist organization, in 2012 Israel issued over 48,000 exit 


\section{The Office of the Deputy Attorney General (International Law)}

permits to Gaza residents and in the first half of 2013 over 26,000 Palestinians were allowed to enter Israel from the Gaza Strip.

4. Israel's policy on this issue came under the scrutiny of the Supreme Court, which has repeatedly held that there is no ground for interfering in it (including in petitions that were filed by the drafters of the present report). Thus for example, His Honor Justice Vogelman held (Ad.P.A. 4620/11 Omiama Hamed Mohamad Kishawi et. al. v. The Minister of Interior et. al. (7.8.12)) that:

"Entry permits to Israel are given to residents of the Gaza Strip in exceptional humanitarian cases only, such as visits for medical purposes. Against this policy background, applications by residents of the Gaza Strip for permits to enter Israel are examined individually only if they are deemed to be based on an exceptional humanitarian need as aforesaid. This court has repeatedly held that no grounds exist for interference in this policy, provided that when exercising their discretion in implementing it, the competent authorities give appropriate weight to humanitarian considerations, that, having regard to the changes which have taken place in the scope of the State's obligations towards the residents of Gaza in the wake of the implementation of the 2005 disengagement plan and the rise to power of Hamas."

5. This issue has come under judicial scrutiny in a long line of cases and in different contexts. For illustration purposes only, here is a partial list of the decided cased concerning the policy examined above: H.C.J. 495/12 Kafrana et. al. v. The Minister of Defense et. al. (24.9.12), H.C.J. 4906/10 Fatima Sharif v. The Minister of Defense (7.7.10), which involved crossing from the Gaza Strip to the West Bank for the purpose of academic studies; H.C.J. 5649/12 Fahima Hamdan et. al. v. The Commander of the Southern Command et. al. (16.8.12), which addressed the issue of Israelis crossing into Gaza; H.C.J. 2748/12 Rafiq Msalem et. al. v. The Military Commander of the West Bank et. al. (16.4.12), which addressed the issue of crossing in order to attend a professional conference; H.C.J. 9657/07 Tzabach Nimer Abed Jerboa et. al. v. The Commander of Military Forces in the West Bank et. al. (24.7.08) and H.C.J. 


\section{The Office of the Deputy Attorney General (International Law)}

1892/10 Nazar Abu Sardana et. al. v. The Commander of Military Forces in the West Bank et. al. (11.8.10), which addressed the issue of crossing for the purpose of family visits.

6. There is no doubt that the aforementioned policy, to some extent, causes individual hardship, however this policy is a regretful side effect of a strategy of terrorism and violence pursued by the Palestinian terrorist organizations, and we can only express our disappointment that the report fails to address or even briefly mention these security threats and the murderous terrorism which continues to be directed, inter alia, against the civilian population of the State of Israel. It is equally regrettable, that the drafters of the abovementioned report did not feel that a proper and balanced report ought to, at the very least, present and discuss the wider context in which the policy is rooted and the rationales which justify it.

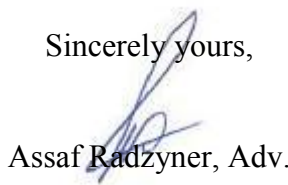




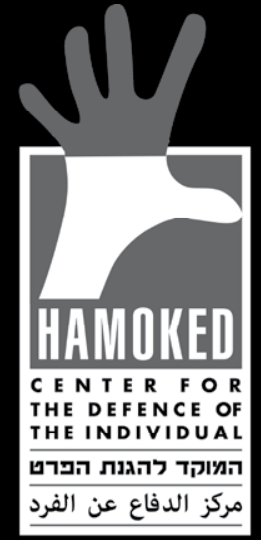

w w w . h a moked.org. i 1

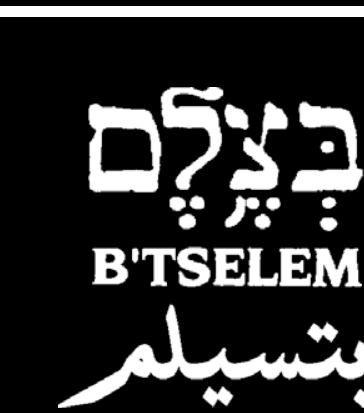

w w w . b t s e 1 e m . o r g 